\title{
The Central Cordilleran Subgroup of Philippine Languages
}

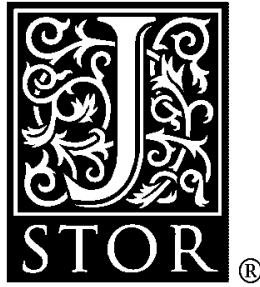

Lawrence A. Reid

Oceanic Linguistics, Vol. 13, No. 1/2, Papers of the First International Conference on Comparative Austronesian Linguistics, 1974: Proto-Austronesian and Western Austronesian. (Summer - Winter, 1974), pp. 511-560.

Stable URL:

http://links.jstor.org/sici?sici=0029-8115\%28197422\%2F24\%2913\%3A1\%2F2\%3C511\%3ATCCSOP\%3E2.0.CO\%3B2-Q

Oceanic Linguistics is currently published by University of Hawai'i Press.

Your use of the JSTOR archive indicates your acceptance of JSTOR's Terms and Conditions of Use, available at http://www.jstor.org/about/terms.html. JSTOR's Terms and Conditions of Use provides, in part, that unless you have obtained prior permission, you may not download an entire issue of a journal or multiple copies of articles, and you may use content in the JSTOR archive only for your personal, non-commercial use.

Please contact the publisher regarding any further use of this work. Publisher contact information may be obtained at http://www.jstor.org/journals/uhp.html.

Each copy of any part of a JSTOR transmission must contain the same copyright notice that appears on the screen or printed page of such transmission.

The JSTOR Archive is a trusted digital repository providing for long-term preservation and access to leading academic journals and scholarly literature from around the world. The Archive is supported by libraries, scholarly societies, publishers, and foundations. It is an initiative of JSTOR, a not-for-profit organization with a mission to help the scholarly community take advantage of advances in technology. For more information regarding JSTOR, please contact support@ jstor.org. 
THE CENTRAL CORDILLERAN SUBGROUP OF PHILIPPINE LANGUAGES ${ }^{1}$

1. INTRODUCTION. The term CENTRAL CORDILLERAN (CC) ${ }^{2}$ is here applied to a group of languages spoken mostly in the mountains of Northern Luzon, Philippines. These languages are Kalinga (spoken in the province of KalingaApayao), Itneg (spoken in Abra), Bontok (spoken in Mountain Province), Kankanay (spoken in the west of Mountain Province and in Benguet), Balangaw (spoken in the east of Mountain Province), and Ifugao (spoken in the province of the same name). The group also includes one language spoken in Nueva Vizcaya--Isinai. ${ }^{3}$

On the basis of various kinds of evidence, to be presented in this paper, it seems probable that these languages all descend from a single parent language, here labeled PROTO CENTRAL CORDILLERAN (PCC). The group shows various degrees of internal cohesion, which may be displayed as in the figure below.

Isinai shows the longest period of independent development, in that it does not share in a number of innovations which appear to be shared exclusively by the other languages, which may be 1 abeled NORTH CENTRAL CORDILLERAN (NCC). Within the latter group, Itneg and Kalinga, and Bontok and 


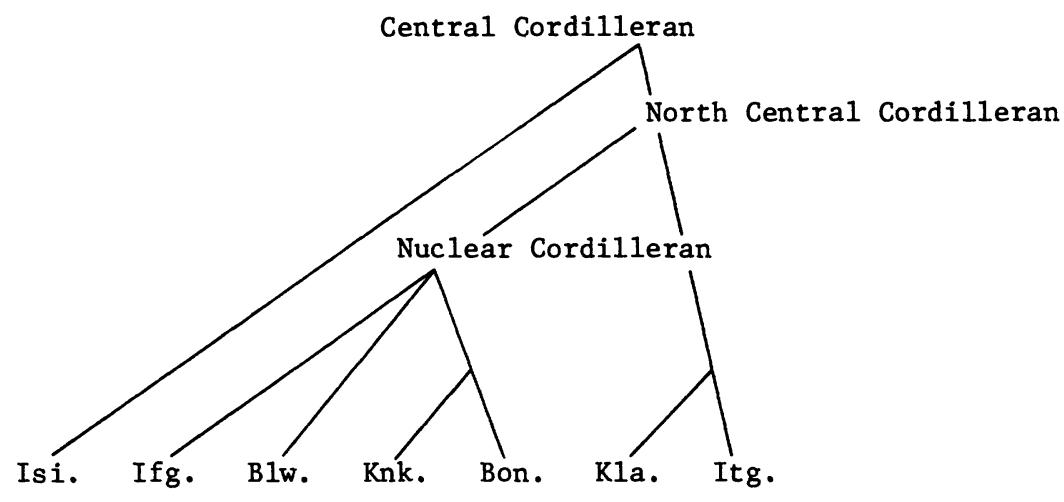

The internal relations of the Central Cordilleran Subgroup

Kankanay form subgroups probably differentiating relatively recently. Bontok-Kankanay, Balangaw and Ifugao form a subgroup here labeled NUCLEAR CORDILLERAN (NC) .

The external relations of the Igorot languages are with the surrounding languages of Northern Luzon, including Ilokano, Isneg, Agta, Atta, Ibanag and Gaddang; and to the south, the group which includes Kallahan, Inibaloi, Karaw and Pangasinan. Although the CC languages share a number of features with the latter group, ${ }^{4}$ other evidence tends to point to a closer relationship with the Ilokano group. Further studies need to be conducted to clarify the situation.

Various lexicostatistic studies have pointed to a subgrouping similar to that postulated here. Thomas and Healey's study (1962) showed Ifugao, Kankanay, Bontok and Sagada (=Northern Kankanay) as forming a subgroup, but Kalinga and Tingguian (=Itneg) were grouped with Ilokano, Isneg and other languages to the north of them. 5 Dyen (1965) delineated an Ifugao subfamily, consisting of the languages spoken in the various Ifugao areas of Kiangan, Mayaoyao, and Hanglulu; an Igorot subfamily consisting of Kankanay, Sagada, Bontok and Bayyu (a town in the south of the Bontok region); and a Kalinga subfamily, consisting of Balbalasang and Pinukpuk, languages spoken in these Kalinga towns. He grouped these three subgroups coordinately with Isinai, Ilokano, and a 
Banagic cluster consisting of the remaining 1 anguages north and east of Kalinga.

Llamzon (1969) employed two of the CC languages in his subgrouping study, Kankanay and Ifugao. Much of the evidence he produced to prove the close relationship of these two languages was not exclusively shared by Ifugao and Kankanay, but can be shown to have been the result of innovations that took place either in PCC, or in Proto-NCC. However, Llamzon was the first to show by qualitative means that Ifugao and Kankanay are part of a subfamily distinct from Ilokano and Ibanag.

2. PHONOLOGY. PCC had a relatively simple phonemic system. It consisted of fourteen consonants, four vowels and stress. This system is retained in only one of the daughter languages, Bontok. The PCC phonemic system can be charted as follows:

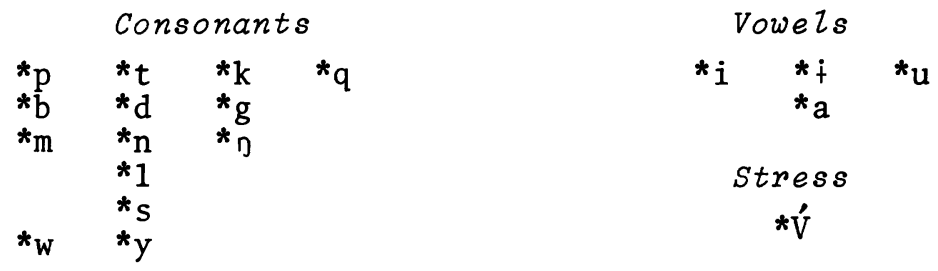

At some early stage, if not in PCC, then in Proto-NCC, the voiced stops developed voiceless variants in syllable initial position. In Bontok and Balangaw the general rule is as follows (Reid 1963, Shetler 1966):

$$
\left[\begin{array}{l}
b \\
d \\
g
\end{array}\right] \rightarrow\left[\begin{array}{l}
f \\
t s \\
k^{h}
\end{array}\right] \quad / \quad v
$$

Kalinga has the following general rule (Gieser 1958):

$$
\left[\begin{array}{l}
\mathrm{b} \\
\mathrm{d} \\
\mathrm{g}
\end{array}\right] \rightarrow\left[\begin{array}{l}
\mathrm{p} \\
\mathrm{j} \\
\mathrm{k}
\end{array}\right] \quad / \quad \mathrm{v}
$$


Some dialects of Ifugao (as Gohang) have the following general rule (Newell 1956):

$$
\left[\begin{array}{l}
\mathrm{b} \\
\mathrm{d} \\
\mathrm{g}
\end{array}\right] \rightarrow\left[\begin{array}{l}
\mathrm{pf} \\
\mathrm{t} \mathrm{s} \\
\mathrm{k}
\end{array}\right] \quad /-\mathrm{V}
$$

In some dialects of Bontok (e.g., Mainit), as we11 as in Kalinga and Ifugao the syllable initial variants optionally occur also in word final position. Various other shifts have occurred in some dialects, e.g., palatalization of syllable initial variants preceding /a/ in Barlig, a town of Eastern Bontok (/b/ also has a variant $\left[\mathrm{p}^{\mathrm{y}}\right]$ preceding /a/ in Guinaang, a town of Kalinga), and retention of voicing in all syllable initial variants, e.g., Mainit [v] and [dz] are variants of /b/ and /d/ respectively. Mainit /g/ occurs as [g] in all positions.

The syllable initial fricative variants do not occur in Isinai, neither do they occur in Kankanay nor the Inlaod (western) dialect of Itneg. They do occur in the Masadiit dialect of Itneg spoken in the Bucloc valley and in the towns of Tiempo and Tubo. It is assumed that Kankanay and Inlaod Itneg lost the variants as a result of the considerable influence of Ilokano upon them, an influence noted in many other areas of the languages besides phonology. Kankanay and Itneg occur geographically between Ilokano and the other languages they are genetically most closely related to, Bontok and Kalinga respectively. It is possible that Isinai has also been influenced in the same manner.

In Inibaloi the fronted voiceless velar $/ \mathrm{k} /$ and the palatal affricate /c/, although underlying phonemes, only occur in syllable initial position, as in the NCC languages. There is evidence that the rule was borrowed into Inibaloi, and probably was not present in the parent language of that group.

One other consonant phoneme, *1, probably also had variant realizations in PCC. In Reid (1972), the reflexes of *1 for Kankanay, Bontok, Balangaw, Kalinga and Ifugao are discussed in some detail. It is not necessary to repeat the details here. Suffice to say that not only in the CC languages but also in 
languages from Batanes in the far north of the Philippines to the Manobo languages in the south, the reconstructed lateral shows variant reflexes determined by the same conditioning factor, i.e., by proximity to a front vowe1, usually $i$. Other environmental factors, such as position in relation to other alveolar consonants, or to word boundaries, and identity of surrounding vowels, are also present in many languages.

The PCC phonemic system developed from ProtoAustronesian in the following way:

Consonants.

PAN *p, *t, ${ }^{*} \mathrm{k},{ }^{*} \mathrm{~b},{ }^{*} \mathrm{~d},{ }^{*} \mathrm{~g},{ }^{*} \mathrm{~m},{ }^{*} \mathrm{n},{ }^{*} \mathrm{n},{ }^{*} 1,{ }^{*} \mathrm{~s}$, ${ }^{*} w$, and ${ }^{*} y$ are reflected as the same sounds in al1 environments in PCC. Note the following evidence (PAN forms are given to the left, PCC to the right of the symbo1):

*pitu > *pitú 'seven', *qatep > qat'p 'roof',

* $x_{2}$ epat [] > *q+pát 'four', *tanem > *tan'm

'plant',

*takut ’ tákut 'fear', *kaRi > *ka1í 'speak, language',

*siku > *siku 'elbow', *manuk > *manúk 'chicken', *bayu ${ }^{\circ}>{ }^{*}$ báyu 'pound', *babuy > *bábuy 'pig', *dilaq > *díla 'tongue', *tuduq > *tudú 'point out',

*qañud > *qánud 'flow', *1ima > *1imá 'five', *xzenem > *q+ntm 'six', *n+ipen > *níptn 'tooth', *bana ${ }^{\circ}$ *bána 'pot', *qutan > *qúţan 'debt', *gatel >*gat+1 'itch', *siji>*sigi 'sift', *qasin > *qasín 'salt', *w2alu' > *walú 'eight', *wasay > *wásay 'axe', * 1 awi ${ }^{\circ}>$ * 1 awí 'rooster's tail feathers'.

A11 reconstructed PAN 1aryngea1s, *X, *x, ${ }^{*} \mathrm{~W},{ }^{*} \mathrm{q},{ }^{*} 7$, ${ }^{*} \mathrm{Q},{ }^{*} \mathrm{~h},{ }^{*} \mathrm{H},{ }^{*} \mathrm{~S}$, as we 11 as initial hiatus, and zero are reflected as glottal stop $\left({ }^{*} q\right)$ word initially and as zero word finally.

\section{Evidence:}

*halqu > *qalqu 'pestle', *x1apuy > *qapúy 'fire', *Wasu[]>*qásu 'dog', *7enem[]>*q+n+m 'six', * $\mathrm{S}_{6}$ iRup > *qígup 'sip', *DaR $\mathrm{DaQ}_{2}>\mathrm{Q}^{\mathrm{R}} \mathrm{dá} 1 \mathrm{a}$ 'blood', *panaq > pána 'bow and arrow', *tebuSu > *tubú 'sugarcane'. 
Medially the laryngeals became * $q$, except between a preceding high front or a high back vowel and a following non-identical vowel, when they became respectively ${ }^{*} y$ and ${ }^{*} w$.

Evidence:

*ba-beHi[] > *ba-baqi 'woman', *buSek[] (>ProtoPhilippine *buhuk) > *buqúk, *Suab > * quwáb

'yawn', *quey > *quwéy 'rattan', *zaqit > *áqit 'sew'.

PAN *j $>*^{*}$.

Evidence:

${ }^{*}$ maja ${ }^{\circ}>{ }^{*}$ mag-qán 'dry', *pusej > *pús+g 'navel'. (But note *n+ajan > *ádan 'name'.)

PAN ${ }^{*} \mathrm{r}$ and ${ }^{*} \mathrm{R}$ are both reflected as PCC *1.7

Evidence:

*raprap > *1áplap 'skin, flay, strip off', *ribu > * 1 ibu 'thousand', *०azar > *ádal 'teach',8 *sarsar > *sálsqil 'beat an object repeatedly',

${ }^{*} \mathrm{Rabi}^{\circ} i^{\circ}>{ }^{*} 1 \mathrm{abi}$ 'night, evening', * $\mathrm{R}_{3}$ akit >

*lákit 'raft', *taR 1 uq > *tálu 'put away, hide', *DapuR > *dapúl 'ashes'.

PAN $* \tilde{n}>\operatorname{PCC} *_{n}$.

Evidence:

*na > *na '3rd person singular Genitive pronoun', ${ }^{*} \tilde{n} i^{\circ} u R>{ }^{*}$ niyúg ${ }^{7}$ 'coconut'.

PAN ${ }^{*} \mathrm{C}>\mathrm{PCC}{ }^{*} \mathrm{~S}$.

Evidence:

*caremin > sálmin 'glass, mirror', *cek[e]1> ${ }^{*} \mathrm{~s}+\mathrm{k} \dot{+} 1$, 'strangle', *cuka ${ }^{\circ}{ }^{*}$ *súka 'vinegar', *guci $>$ *gusí 'kind of $j a r^{\prime}$.

PAN ${ }^{*} \mathrm{C}>\mathrm{PCC} * \mathrm{t}$.

Evidence:

*Caqi > *táqi 'feces', ${ }^{*} \mathrm{CumaS}_{2}>$ *túma 'louse', *maCa > *matá 'eye'. 
Vowels

PAN *i, *a, *u, *e are reflected respectively as PCC *i, *a, *u, $\star_{\dot{q}}$. The latter vowel was a mid to high central vowel, and is reflected as such in Bontok, Kankanay, Itneg, and in some environments in Balangaw. Adequate evidence is given in the forms cited above.

PAN *-ey and *-ay, became PCC *-+y.

Evidence:

*maCey > *mat $\dot{+}$ ' 'die', *pajey > *págły 'rice plant', *qu ${ }^{\circ}$ ey > *quwiy 'rattan'; *t+ytiy 'step, path'>*t+yt+y '1adder', *tapay > *táp+y 'yeast, riçe beer', *balay > *bal'y 'house', *kiDay > *kidty 'eyebrow'.

In addition to the Bontok-Kankanay subgroup, Isinai, Kalinga, and Batad Ifugao (IfgBt) retain evidence of the reflex, *-+y. In these 1anguages, PAN *e is regularly reflected as 0 , and the sequence *-ey is reflected as -oy (IfgBt. sometimes shows - uy from * $+y)$. PCC *matiy > Isi., Kla, IfgBt. matóy 'die'; PCC *págły > I,si. páxoy, Kla. págoy, IfgBt. páguy 'rice'; PCC *t+ytiy > Isi. toytoy 'ladder'; PCC *balíy > Isi. béoy, Kla. boloy, IfgBt. baluy 'house'; PCC *quwty > Isi. wéoy, Kla. qiwoy, IfgBt. quwoy 'rattan'.

The evidence is complicated by a considerable number of forms showing apparent -ay reflexes in each of the languages where the expected reflex is either - +y or -oy, e.g., PAN *sakay > Bon. sakay 'mount', *lantay 'floor covering' > Bon. Zantay 'bridge', *wasay > Bon., Isi. wásay 'axe'. With such forms it is necessary to assume that they were either borrowed into PCC from a language such as Ilokano (in which *-ay and *-ey >-ay) after the *-ay > - $+y$ rule ceased to operate, but before Isinai diverged from the parent group, or else they were independently borrowed, not only into Bontok and Isinai, but a1so into each of the other branches of the CC group, since such forms occur also in most of the other CC languages.

PAN *-ew and *-aw became PCC *-iw. 
Evidence:

PAN *buR 3 ew > *bُ $\dot{+} 1+$ w 'chase away'9, *kayaw > *káy iw 'head hunting', *pakaw > pák+w 'handle', *pâNtaw > *pántiw 'overlook (house)', *silaw > ${ }^{*} \operatorname{sil} \dot{+}_{\mathrm{w}}$ 'torch'.10

As with the $-y$ final diphthongs, so with the $-w$ finals, there are a considerable number of forms reconstructable for PCC where the vowel is a not $\dot{i}$. Such forms include *puláw 'white', *dáyaw 'honor', *bánkaw 'spear', *sáyaw 'dance', ‘kálaw 'hornbill'. These forms must probably be also considered as early borrowings into PCC, or subsequent independent borrowings into the daughter languages.

Loss of syllable final *-q

Although in Kalinga, Balangaw and Ifugao, $q$ occurs in syllable final position, it appears to be in every instance a reflex of $* k$. $q$ as a reflex of ${ }^{*} q$ does not occur syllable finally in these languages. (The Isinai situation will be discussed below.) It is probable then that a phonotactic restriction on the syllable final occurrence of *q existed in PCC. The evidence suggests that word bases that came into PCC with a medial *-qC-cluster were metathesized, whereas word final glottal stops were lost. Balangaw, Bontok and Kankanay generally show a $-\mathrm{C} q-$ correspondence to a - $q \mathrm{C}$ - sequence in languages not in the CC subgroup. Ifugao generally reflects $\varnothing$ for * $q$, whether in a consonant cluster or between vowels.

\section{Evidence:}

*sapq $\dot{+y}>$ Bon., Knk. sapq $\dot{t y}$, Ifg. hape 'dry in the sun' (but note Ibl. saqpiy, Kln. haqpiy), *babqa > Bon., Knk. babqa, Blw. bubqa, Ifg. buba 'tooth' (but note I1t. $b+q b a),{ }^{*} g u g q u>$ Bon. gugqu, Ifg. gugu 'scratch' (but note Ilt. guqgu, Kln. guqguq), *d+tqal > Bon., Knk. ditqal, Blw. ditqal, Ifg. dotal 'floor' (but note Ilt. diqtay, Ivt. raqtay), *na-magqan-an > Bon. namagqanan, Ifg. namaganan 'dry', *gabqun > Bon. gabqun, Ifg. gabqun gabun 'cover'.

The evidence for Itneg and Kalinga is not clear from the available data, but they also seem to retain the consonant-glottal stop sequence, as do Bontok, Kankanay and Balangaw, e.g., K1a. qalqo 
'pestle', tunqal 'bone'. Balangaw shows some forms where the postconsonantal glottal stop has been lost, e.g., qalo 'pestle', tonal 'bone'. These forms may be borrowings from Ifugao.

Bontok and Kankanay have a metathesis rule synchronically operating in which clusters of -qCformed by vowel syncope become $-\mathrm{C} q-$, e.g., Bon., Knk. $q i-+q \dot{+} \dot{+} \dot{+}+q i s q \dot{+} k$ 'to plant (associative focus)', Bon. $n a-+q \dot{+}+\dot{+} z \rightarrow n a b q \dot{+} z$ 'wet'. The rule was probably formerly operative in Balangaw, but appears only in relatively few forms. It was, moreover, generalized to include sequences with either glottal stop or fricative (B1w. $h<{ }^{*}$ s), e.g., B1w. $q i-+$ $h \wedge g \dot{+} p \rightarrow q i g h \dot{+} p$ 'bring in' (cf. Bon. $q i s g \dot{+} p$ ), $p \wedge h \wedge d+$

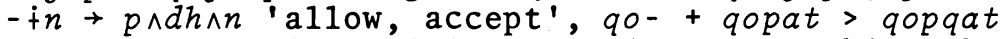
'four each', $q \dot{t}-+q \dot{+} n \dot{+} m>q \dot{+} n q \dot{+} m$ ' $\mathrm{six}$ each'. The fact that these (at least the latter two) are relic forms is supported by the restructuring which has occurred in some forms where glottal metathesis has taken place, e.g., Blw. nagqah 'to fall', although from an earlier *na- $+* q+g a h$ is now interpreted as $n a-+q \dot{+} g q a h$, the root form with glottal stop occurring in other constructions. Moreover - $q \mathrm{C}-\mathrm{clusters}$ occur in Balangaw in forms in which $q$ reflects an earlier *k, e.g., ma- + Zoqon $\rightarrow$ maqlonll, Zoqon + -on $\rightarrow$ Zoqnon 'dry up, wilt'.

Ifugao may also have participated in a - $q \mathrm{C}$ - metathesis rule, but since ${ }^{*} q$ became $\emptyset$ in Ifugao there is no internal evidence to prove its former existence in the derived forms in this language. Seeing there is no evidence to support a closer relationship between Balangaw and the Bontok-Kankanay subgroup than between Ifugao and these languages, it is more satisfying to assume that the metathesis rule operated in Proto Nuclear Cordilleran, the parent 1anguage of Balangaw, Bontok-Kankanay and Ifugao, and it was subsequentiy lost in Ifugao.

Kalinga and Itneg appear to avoid clusters of the - $q \mathrm{C}$ - type (where $q<\star_{\mathrm{q}}$ ) by eliminating the vowel syncope rule in just these environments. Thus Itg. $q i-+q \dot{+}+\dot{+} b \rightarrow q i y+n \dot{+} b$ 'to close a door' (cf. Bon. $q$ in $q \dot{+} b), m a-+q \dot{+} z+d \rightarrow \operatorname{maq} \dot{+} z+d$ 'to sink', Kla. na$+q \circ b \circ l \rightarrow n a q 0 b o l$ 'wet' (cf. Bon. nabqil), $q \mathbf{i}-+$ qosoq $\rightarrow$ qiyosoq 'plant' (cf. Bon. qisqik). 
Isinai, like many of the other CC languages reflects ${ }^{*} \mathrm{k}$ as $q$, so that synchronically, glottal stop now frequently appears at the end of a syllable, e.g., CC *sakgud > Isi. saqgud 'horn'. However there is now evidence to suggest that at the time when Isinai diverged from PCC it did not participate in the morpheme structure restriction on syllable final glottal stop discussed above. Although some forms exist which, as in Ifugao, have lost original glotal stop, e.g., Isi. bava' tooth' (< PCC *babqa), guxu 'scratch' (< PCC *gugqu), and thus do not provide evidence for the *-Cq- sequence in PCC, there are several Isinai forms which do reflect such a sequence, e.g., *qalqu > Isi. qequ 'pestle' (PCC *al regularly becomes Isi. e), *banq $+\mathrm{g}>$ Isi. manqo $\chi^{12}$ 'smal1', *sagqtn > Isi. saxqon 'near', *tagq $+y>$ Isi. $q a$-taxqoy 'up'.

Isinai, like Kalinga and Itneg, does not show evidence for having once had a metathesis rule to invert derived glottal stop-consonant clusters.

Whereas Kalinga and Itneg avoided such clusters through loss of a vowel syncope rule, Isinai has retained the syncope rule and tolerates the derived clusters with initial glottal stop, e.g., Isi. $q i-+$ $q 0 n o b \rightarrow q i q n o b$ 'close a door' (cf. Bon. qinqtb, Kla. qiyonob), Isi. na- + qomot $\rightarrow$ naqmot 'bathed' (cf. Bon. namqis).

It appears then that although it is possible to postulate a morpheme structure rule for PCC which resulted in the metathesis of glottal stop-consonant clusters in roots, it is not possible to postulate a metathesis rule for derived glottal stop-consonant clusters (such as those resulting from vowel syncope) until Proto Nuclear Cordilleran developed.

3. PRONOUNS. PCC had three distinct sets of pronouns: long form Nominatives, short form Nominatives and Genitives. The Oblique pronouns were a combination of the personal oblique case marker plus the long form Nominative pronouns. As can be seen by the preceding statement, the term Nominative when applied to the long form pronouns specifies only one of several functions which the set had. These included: 
a. Subject of non-actor focus sentences,

e.g., Bon. binanun nan laláki sakqin

Blw. binajon hen laláqe haq^n

Kla. binanon din laláqi sakon woke man me

'The man woke me up.'

b. Topicalized Subject or agent. (Similar examples could be provided from each of the CC languages.) e.g., Bon. sakqin, qinm $\dot{+} y a k$.

'As for me, I went.' sakqìn, binánun nan laláki me woke man

'As for me, the man woke me up.' sakqìn, binánunku siya me woke-I him

'As for me, I woke him up.'

c. Predicate of an equational sentence type.

e.g., Bon. sakqin nan namajun qan siya I the woke him

'I was the one who woke him up.'

Chart I lists the reconstructed long form Nominative pronouns with their reflexes in the daughter languages.

The variation that is evident in a number of the reconstructed forms is the result of the reduction of the **daqi- case formative which was present in pre-Central Cordilleran. This formative is still present in Bontok on the daqita '1+2 $\mathrm{s.}^{\prime}$ and daqida ' 3 p.' pronouns although in variation with reduced forms data and dida respectively. The pre-CC forms **daqikami, **daqikayu, and **daqitaku have all been reduced, to three syllables in PCC and present1y in several of the daughter languages, and in the case of the ' $1 \mathrm{p.'}$ ' and ' $2 \mathrm{p}$.' forms, to two syllables by loss of the medial vowel in Isinai, Balangaw and Ifugao.

The $1+2 \mathrm{p}$. pronominal formative *-taku was an innovation in PCC, the expected form being either *-tam or *-tayu (based on evidence from the Northern and Southern Cordilleran languages). The presence of a reflex ditaqu in Isinai is confirmatory evidence that Isinai belongs to the CC subgroup. 


\begin{tabular}{|c|c|c|c|c|c|c|c|}
\hline & PCC & Isi. & Itg. & $\mathrm{K} 1 \mathrm{a} .13$ & Bon., Knk. & $\mathrm{B} 1 \mathrm{w}$. & Ifg. \\
\hline $1 \mathrm{~s}$. & $\begin{array}{l}\text { *siyakin } \\
\text { *sakq+n }\end{array}$ & taqon & diyak $+n$ & sákon & sakq $+n$ & $\mathrm{haq} \wedge \mathrm{n}$ & haqqin \\
\hline $2 \mathrm{~s}$. & $\begin{array}{l}\text { *siqika } \\
\text { *sikqa }\end{array}$ & siqa & dika & sika & $\mathrm{sikqa}$ & héqa & heqqa \\
\hline $1+2 \mathrm{~s}$ & $\begin{array}{l}\text { *daqita } \\
\text { *dita } \\
\text { *data }\end{array}$ & dita & dita & dita & $\begin{array}{l}\text { daqita } \\
\text { data }\end{array}$ & dita & dita \\
\hline $3 \mathrm{~s}$ & *siya & siya & siya & siya & siya & hiy^ & hiya \\
\hline $1 \mathrm{p}$. & $\begin{array}{l}\text { *dakami } \\
\text { *dikami }\end{array}$ & daqmi & dikami & dikami & dakami & $\mathrm{d}+\mathrm{qn} i$ & daqmi \\
\hline $2 \mathrm{p}$. & $\begin{array}{l}\text { *dakayu } \\
\text { *dikayu }\end{array}$ & daqyu & dikayu & dikayu & dakayu & $d \dot{q} q u$ & daqyu \\
\hline $1+2 \mathrm{p}$ & $\begin{array}{l}\text { *dataku } \\
\text { *ditaku }\end{array}$ & ditaqu & ditayu & ditako & dataku & ditaaw & dituqu \\
\hline $3 \mathrm{p}$ & $\begin{array}{l}* \text { daqida } \\
* \text { dida }\end{array}$ & díra & dayda & $\overline{d i d a}$ & $\begin{array}{l}\text { daqida } \\
\text { dida }\end{array}$ & did.^ & $\mathrm{dida}$ \\
\hline
\end{tabular}


The presence of ditayu in Itneg would tend to provide counter-evidence to the claim made in this paper that Itneg subgroups with Kalinga rather than with Ilokano. Itneg however has had a long history of contact with Ilokano and shows a considerable amount of borrowing from that language. I assume that Itg. tayu is a borrowing from Ilokano. Note that the formative di- on Itg. ditayu is not found in the Ilokano pronominal system, but is the reduced form of **daqi-, which Kalinga consistently uses. It appears that the parent language of Kalinga and Itneg consistently used the PCC *di-pronominal variants for $1+2$ s., 1 p., 2 p. and $1+2$ p. Itneg has also extended the use of the $d i$ formative to replace initial *si- in the $1 \mathrm{~s}$. variant *siyakin, as well as the $2 \mathrm{~s}$. variant *siqika, producing the innovations Itg. diyakin '1 s.' and dika '2 s.'

Chart II lists the reconstructed short form Nominative pronouns with their reflexes in the daughter languages. In PCC the short form Nominative pronouns (all of which were enclitics to the Predicate) functioned as follows:

a. Subject of actor focus sentences.

$$
\text { e.g., Bon. } \begin{gathered}
q i n m \dot{t} y-a k \\
\text { went -I }
\end{gathered}
$$

b. Subject of non-verbal sentences.

$$
\begin{aligned}
& \text { e.g., Bon. lalaki-yak 'I am a man.' } \\
& \text { man - I } \\
& \text { wadqáy-ak si na 'I am here.' } \\
& \text { there is - I here } \\
& \text { qanqandu-wak } \\
& \text { 'I am ta11.' }
\end{aligned}
$$

Itneg is the only language which has replaced an inherited form with a borrowing, Itg. tayu ' $1+2 \mathrm{p} . '$ is, as discussed above, a probable borrowing from Ilokano.

Chart III lists the reconstructed Genitive clitic pronouns with their reflexes in the daughter languages. As in other Austronesian languages, they function as agent in non-actor focus sentences, and as possessor in possessive phrases. All the daughter languages reflect full and reduced forms for the first and second person singular pronouns. The full 


\begin{tabular}{|c|c|c|c|c|c|c|c|}
\hline & PCC & Isi. & Itg. & $\mathrm{K} 1 \mathrm{a}$. & Bon. , Knk & B1w. & Ifg. \\
\hline $1 \mathrm{~s}$. & $*-a k$ & $-a q,-q$ & $-a k$ & - ak & $-a k$ & $-a q$ & $-a q$ \\
\hline $2 \mathrm{~s}$. & $*-\mathrm{ka}$ & $-q a$ & $-\mathrm{ka}$ & $-k a$ & $-\mathrm{ka}$ & $-q a$ & $-q a$ \\
\hline $1+2 \mathrm{~s}$ & $*-t a$ & $-t a$ & $-t a$ & $-t a$ & $-t a$ & $-t a$ & $-t a$ \\
\hline $3 \mathrm{~s}$ & $\varnothing$ & $\emptyset$ & $\emptyset$ & $\emptyset$ & $\emptyset$ & $\emptyset$ & $\varnothing$ \\
\hline $1 \mathrm{p}$. & $*-\mathrm{kami}$ & qami & -kami & - kamí & -kami & - qani & -qami \\
\hline $2 \mathrm{p}$. & *-kayu & qayu & -kayu & -kayú & -kayu & - qayu & -qayu \\
\hline $1+2 \mathrm{p}$ & $*-$ taku & taqu & -tayu & - tak6 & $-t a k u$ & - taaw & - tuqu \\
\hline $3 \mathrm{p}$. & $*-\mathrm{da}$ & $-\mathrm{da},-\mathrm{ra}$ & $-d a$ & $-d a$ & $-d a$ & $-d \wedge$ & $-d a$ \\
\hline
\end{tabular}




\begin{tabular}{|c|c|c|c|c|c|c|c|}
\hline & $\mathrm{PCC}$ & Isi. & Itg. & $\mathrm{Kla}$. & Bon., Kn & B1w. & Ifg. \\
\hline $1 \mathrm{~s}$. & $*-\mathrm{ku}, *-\mathrm{k}$ & $-q u,-q$ & $-k u,-k$ & $-\mathrm{ko},-\mathrm{k}$ & $-\mathrm{ku},-\mathrm{k}$ & $-q 0,-q$ & $-q u,-q$ \\
\hline $2 \mathrm{~s}$. & $*-\mathrm{mu}, *-\mathrm{m}$ & $-m u,-m$ & $-n u,-m$ & $-\mathrm{no},-\mathrm{m}$ & $-m u,-m$ & $-\mathrm{no},-\mathrm{m}$ & $-m u,-m$ \\
\hline $1+2 \mathrm{~s}$. & $*-t a$ & $-t a$ & $-t a$ & $-t a$ & $-t a$ & $-t a$ & $-t a$ \\
\hline $3 \mathrm{~s}$. & $*-n a$ & $-n a$ & -na & $-n a$ & $-n a$ & $-n a$ & $-n a$ \\
\hline $1 \mathrm{p}$. & $*-\mathrm{mi}$ & $-m i$ & $-m i$ & $-m i$ & $-\mathrm{mi}$ & $-n i$ & $-m i$ \\
\hline $2 \mathrm{p}$. & $*-y u$ & $-y u$ & $-y u$ & $-y u$ & $-y u$ & $-y u$ & $-y u$ \\
\hline $1+2 \mathrm{p}$ & $*-t a k u$ & - taqu & - tayu & - tako & - taku & $\begin{array}{l}\text {-taaw } \\
\text { - taqaw }\end{array}$ & $-t u q u$ \\
\hline $3 \mathrm{p}$. & $*-\mathrm{da}$ & $-\mathrm{da},-\mathrm{ra}$ & $-d a$ & $-d a$ & $-d a$ & $-d \wedge$ & $-d a$ \\
\hline
\end{tabular}


forms occur as clitics on consonant-final words, the reduced forms occur as clitics on vowel final words, e.g., Bon. qábun-ku 'my house', qásu-k 'my dog'.

It should be noted that Itneg, Kalinga and Balangaw have $n$ - initial full forms for the second person singular genitive pronoun. That these forms are a secondary development in these languages is suggested by the fact that the reduced form of the pronoun remains $-m$ and is not $-n$. What then was the reason for the change from *-mu to -nu? A possible explanation appears when the conditional morpheme 'if' is considered. Many of the languages of the Northern Philippines show reflexes of *nu ' if'. However Central Cordilleran languages generally reflect a PCC *mu 'if' (Isi. mo, Bon. mu, Knk. mu, Ifg. (Amganad) $m u$ qon, Ifg. (Bayninan) muqun). In just those CC 1anguages which have nu for the $2 \mathrm{~s}$. Genitive pronoun (Kalinga, Itneg and Balangaw), the conditional marker is also $n u$ and not the expected $m u$. It is possible that these three languages replaced the innovated $m u$ ' if' with borrowed $n u$ (probably from Ilokano), this change stimulating an analogous change in the homophonous $2 \mathrm{~s}$. pronoun.

Balangaw has analogized further, changing $-m i$ to $n i$ so that all nasal initial Genitive pronouns begin with $n$ (B1w. no '2 s.', na' $3 \mathrm{s.'}$, and $n i$ '1 p.'). The $1 \mathrm{p}$. form was then extrapolated to the Nominative series, producing $\mathrm{B} 1 \mathrm{w}$. qani and $d \dot{+} q n i$.

4. CASE MARKING PARTICLES. Reconstructing the case marking system of PCC is a difficult task, because of the large number of changes that have taken place, both in the functions of the markers as we 11 as in their forms, and because for some languages full information is not available about the systems. On the basis of what is known of the CC languages and other Philippine languages, it is necessary to postulate at least Nominative, Genitive and Oblique case marking sets, in addition to $\mathrm{T}$ ime and Locative markers. Within the sets it is necessary to postulate distinctions correlatable with the semantic features of the following substantive. At least the following distinctions are relevant for PCC: singular versus plura1, personal versus common, and specific versus nonspecific. Various other distinctions 
are made within the daughter languages but do not appear to be reconstructable for the parent language.

Chart IV provides the data upon which the reconstructions are based. Itneg data will be presented separately. The reconstructed system appears in Chart V. Where insufficient data exist, as for the plural, common oblique marker, no reconstruction is attempted.

4.1 Genitive markers. All of the CC languages precede a substantive possessor, and the agent of the so-called passive constructions, by a set of markers which is characterized by the use of an enclitic $-n$ on vowel final preceding stems. A form * $(-n)$ is therefore reconstructed. This form in the daughter languages co-occurs with one of several other markers, depending on the semantic features of the following substantive. The personal forms are reconstructable as * $\emptyset$ 'personal singular', and *da 'personal plural'. The *qan form appearing in Isinai, will be explained in the discussion of the oblique markers below. I can provide no satisfactory explanation at the present time for Kla. qod personal singular Genitive marker.

The enclitic - $n$ also co-occurs with particles which precede common substantives. These particles are in most instances identical with the Nominative case marking particles and are discussed in the next section.

4.2 Nominative markers. The personal Nominative markers are reconstructed as *si 'personal singular' and *da 'personal plural'. The only language which shows an innovation is Balangaw with qah (<*qas). In Bontok, qas and $s i$ are alternates for the oblique marker, qas occurring in deliberate speech, si occurring in normal speech after consonant final stems. The same alternation may have been present in $\mathrm{Ba}$ langaw with subsequent loss of the oblique alternant $s i$ and substitution of the qas form for the homophonous form which marked Nominative personal singular. For further discussion of Balangaw and Bontok qas see Sec. 4.4. 
Isinai

\begin{tabular}{|c|c|c|c|}
\hline \multirow{3}{*}{ Genitive } & \multirow[b]{2}{*}{ sg. } & Personal & \multirow{2}{*}{$\begin{array}{l}\text { Common } \\
\begin{array}{l}(-n) \text { si } \\
(-n) d i\end{array}\end{array}$} \\
\hline & & $(-n) \emptyset \sim(q a n)$ & \\
\hline & $\mathrm{p} 1$. & $(-n) d a$ & $\begin{array}{l}(-n) \text { di.. } \\
- \text { dari }\end{array}$ \\
\hline \multirow{2}{*}{ Nominative } & sg. & $s i \sim-t$ & $\mathrm{di}$ \\
\hline & p1. & $\mathrm{da}$ & $\begin{array}{l}\text { di... } \\
\text {-dari }\end{array}$ \\
\hline \multirow{2}{*}{ Oblique } & sg. & $q i$ & $s i \sim-t$ \\
\hline & p1. & & \\
\hline \multirow[b]{2}{*}{ Locative } & & & $s i \sim-t$ \\
\hline & & & $\begin{array}{l}\operatorname{sir} i \sim \\
-t d i\end{array}$ \\
\hline \multirow{2}{*}{ Time } & & & $\begin{array}{l}\text { si... - ad } \\
\sim-t\end{array}$ \\
\hline & & & $s i \sim-t$ \\
\hline
\end{tabular}

CHART IV (Part I) Case marking particles in Central Cordizzeran Zanguages 
Kaling a

\begin{tabular}{|c|c|c|c|}
\hline \multirow{3}{*}{ Genitive } & & Personal & Common \\
\hline & sg. & $(-n)$ qod & $\begin{array}{l}(-n) \operatorname{di}(t) \\
(-n) \operatorname{din}\end{array}$ \\
\hline & $\mathrm{p} 1$. & $(-n) d a$ & $\begin{array}{l}(-n) \text { dat } \\
(-n) \text { dan }\end{array}$ \\
\hline \multirow{2}{*}{ Nominative } & sg. & si & $\begin{array}{l}\text { dit } \sim-t \\
\text { nan } \sim-n\end{array}$ \\
\hline & p1. & $\mathrm{da}$ & $\begin{array}{l}\text { dat } \\
\text { dan }\end{array}$ \\
\hline \multirow{2}{*}{ Oblique } & sg. & qan & $\begin{array}{l}\text { si } \sim-s \sim-q \\
\text { sit, sin }\end{array}$ \\
\hline & $\mathrm{p} 1$. & qan da & $\begin{array}{l}\text { si dat } \\
\text { si dan }\end{array}$ \\
\hline \multirow{2}{*}{ Locative } & & & $\begin{array}{l}\text { si } \sim-s \sim-q \\
\text { sin } \sim-s \text { nan } \sim-q \text { nan } \\
\text { sit } \sim-s \text { dit } \sim-q \text { dit }\end{array}$ \\
\hline & & & $\begin{array}{l}\text { qod } \sim-d \sim-q \\
\text { (Lubuagan qad) }\end{array}$ \\
\hline Time & & & sit, sin \\
\hline
\end{tabular}

CHART IV (Part II) Case marking particles in

Central Cordizleran Zanguages 


\begin{tabular}{|c|c|c|c|}
\hline & & & nay \\
\hline \multirow{3}{*}{ Genitive } & \multirow[b]{2}{*}{ sg. } & Personal & Common \\
\hline & & $(-n) \emptyset$ & $\begin{array}{ll}(-n) & \text { di } \\
(-n) & \text { nan } \\
(-n) & \text { san } \\
(-n) & \text { din }\end{array}$ \\
\hline & $\mathrm{p} 1$. & $(-n) d a$ & \\
\hline \multirow{2}{*}{ Nominative } & sg. & $\begin{array}{l}\mathrm{si} \\
\operatorname{din} \mathrm{si}\end{array}$ & $\begin{array}{l}\text { di } \\
\text { nan } \\
\text { san } \\
\text { din }\end{array}$ \\
\hline & $\mathrm{p} 1$. & $\begin{array}{l}\mathrm{da} \\
\mathrm{din} \mathrm{da}\end{array}$ & $\begin{array}{l}\text { nan } \\
\text { san } \\
\text { din }\end{array}$ \\
\hline \multirow{2}{*}{ Oblique } & sg. & $\mathrm{k}+\mathrm{n}$ & $\begin{array}{l}\text { qis } \sim-s \\
\text { qis } \sim-s \text { nan } \\
\text { qis } \sim-s \text { san }\end{array}$ \\
\hline & $\mathrm{p} 1$ & $\mathrm{k}+\mathrm{n} \mathrm{da}$ & \\
\hline \multirow{2}{*}{ Locative } & & $\begin{array}{l}\text { qis } k+n \\
\text { qis } k+n \text { da }\end{array}$ & $\begin{array}{l}\text { qis } \\
\text { qis nan } \\
\text { qis san } \\
\text { qis din }\end{array}$ \\
\hline & & & qid \\
\hline Time & & & $\begin{array}{l}\text { qis } \\
\text { qis nan } \\
\text { qis din } \\
\text { qid }\end{array}$ \\
\hline
\end{tabular}

CHART IV (Part III) Case marking particles in Central Cordizleran languages 
Central Cordilleran subgroup

\section{Bontok}

\begin{tabular}{|c|c|c|c|}
\hline \multirow{3}{*}{ Genitive } & & Personal & Common \\
\hline & sg. & $(-n) \varnothing$ & $\begin{array}{ll}(-n) & \text { si } \\
(-n) & \text { nan } \\
(-n) & \text { san }\end{array}$ \\
\hline & $\mathrm{p} 1$. & $(-n) d a$ & $\begin{array}{l}(-n) \text { nan } d a \\
(-n) \text { san da }\end{array}$ \\
\hline \multirow{2}{*}{ Nominative } & sg. & si & $\begin{array}{l}\text { nan } \\
\text { san }\end{array}$ \\
\hline & $\mathrm{p} 1$. & $\begin{array}{l}\mathrm{da} \\
\mathrm{da}\end{array}$ & $\begin{array}{l}\operatorname{nan} d a \\
\operatorname{san} d a\end{array}$ \\
\hline \multirow{2}{*}{ Ob1ique } & sg. & $-n \sim q a n$ & $\begin{array}{l}\text { si } \sim \text { qas } \sim-\text { s } \\
\text { si } \sim \text { qas nan } \\
\text { si qas san }\end{array}$ \\
\hline & $\mathrm{p} 1$. & $\begin{array}{c}-\mathrm{n} \text { da } \sim \\
\text { qan da }\end{array}$ & \\
\hline \multirow{2}{*}{ Locative } & & $\begin{array}{l}\text { qas qan } \\
\text { qas qan da }\end{array}$ & $\begin{array}{l}\text { qas } \sim-s \\
\text { qas nan } \\
\text { qas san }\end{array}$ \\
\hline & & & qad \\
\hline \multirow{2}{*}{ Time } & & & $\begin{array}{l}\text { qas } \sim-s \\
\text { qas nan } \\
\text { qas san }\end{array}$ \\
\hline & & & qad \\
\hline
\end{tabular}

CHART IV (Part IV) Case marking particles in Central Cordizzeran Zanguages 
Ifugao

\begin{tabular}{|c|c|c|c|}
\hline \multirow{3}{*}{ Genitive } & & Persona1 & Common \\
\hline & sg. & $(-n) \emptyset$ & $(-n)$ nan \\
\hline & p1. & & \\
\hline \multirow{2}{*}{ Nominative } & sg. & hi & $\begin{array}{l}\text { (ha) din } \\
\text { (ha) nan }\end{array}$ \\
\hline & $\mathrm{p} 1$ & da & $\begin{array}{l}\text { dídan } \\
\text { nádan }\end{array}$ \\
\hline \multirow{2}{*}{ Oblique } & sg. & $-n \sim$ qay & $\begin{array}{l}h i \sim-h \\
h i \sim-h \text { nan }\end{array}$ \\
\hline & p1. & & \\
\hline \multirow[b]{2}{*}{ Locative } & & & hi \\
\hline & & & qad \\
\hline \multirow{3}{*}{ Time } & & & $h i \sim-h$ \\
\hline & & & $\operatorname{qad} \sim-\mathrm{d}$ \\
\hline & & & din \\
\hline
\end{tabular}

CHART IV (Part V) Case marking particles in Central Cordizzeran Zanguages 


\section{Balangaw}

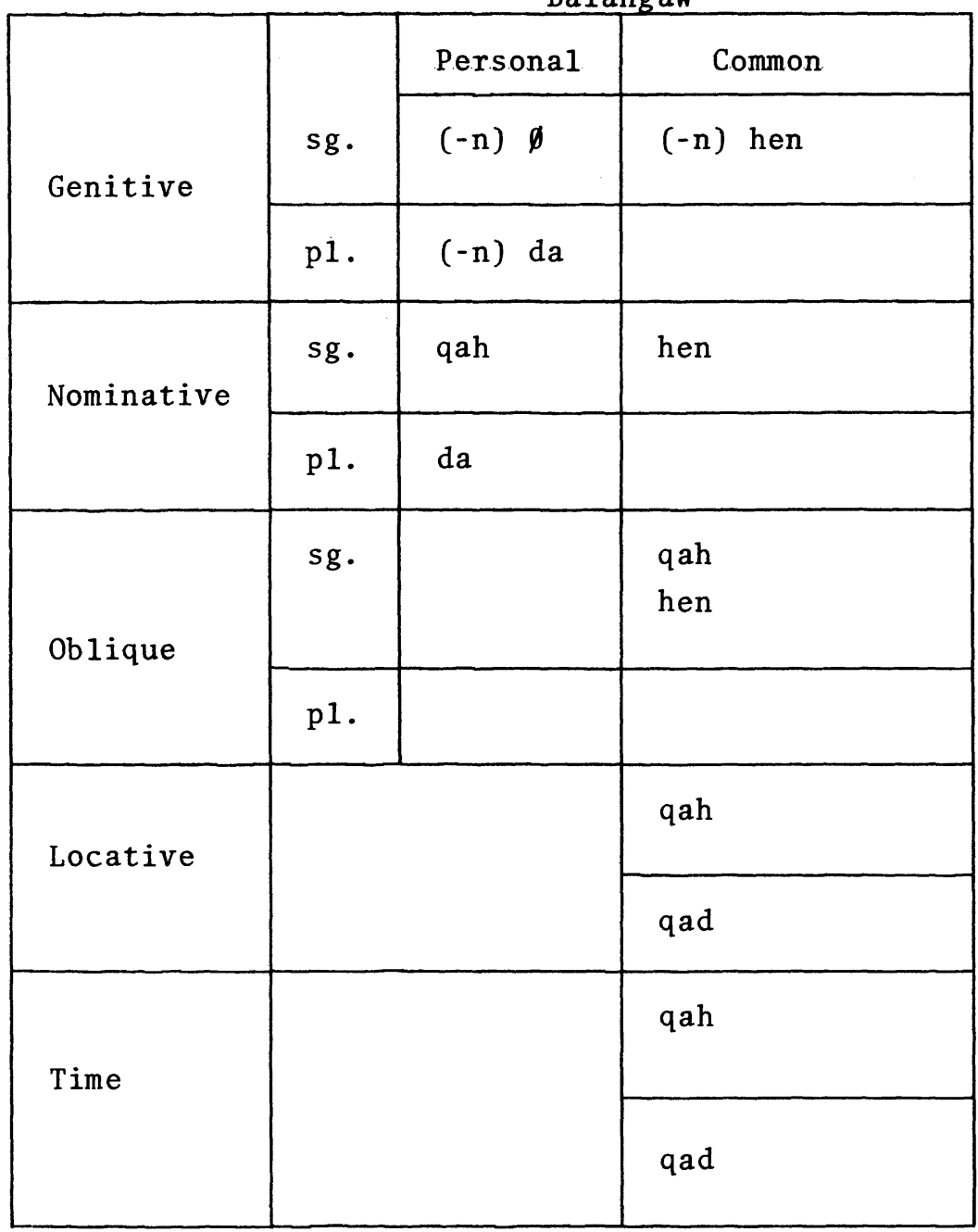

CHART IV (Part VI) Case marking particles in Central Cordizzeran Zanguages 


\begin{tabular}{|c|c|c|c|}
\hline & & Persona & Common \\
\hline \multirow{2}{*}{ Genitive } & sg. & $*(-n) \emptyset$ & $\begin{array}{l}*(-n) \text { di } \\
*(-n) \text { di nan }\end{array}$ \\
\hline & $\mathrm{p} 1$. & $*(-n) d a$ & $\begin{array}{l}*(-n) \text { dadi } \\
*(-n) \text { dadi nan }\end{array}$ \\
\hline \multirow{2}{*}{ Nominative } & sg. & ${ }^{*} \mathrm{si}$ & $\begin{array}{l}* \text { di } \\
* \text { di nan }\end{array}$ \\
\hline & $\mathrm{p} 1$. & $* \mathrm{da}$ & $\begin{array}{l}\text { *dadi } \\
* \text { dadi nan }\end{array}$ \\
\hline \multirow{2}{*}{ Ob1ique } & sg. & ${ }^{*} \mathrm{kan}(\mathrm{i})$ & $\begin{array}{l}{ }^{*} \text { si } \sim *_{-s} \\
{ }^{*} \text { si nan } \sim \text { *s nan }\end{array}$ \\
\hline & p1. & ${ }^{*} \mathrm{kan} \mathrm{da}$ & \\
\hline Location & & & $\begin{array}{l}{ }^{*} \text { qad } \sim *-d \\
\text { *qas } \sim *-s \\
\text { *qas nan } \sim \text { *s nan }\end{array}$ \\
\hline Time & & & $\begin{array}{l}{ }^{*} \text { qad } \sim *-d \\
* \text { qas } \sim *-s \\
* \text { qas nan } \sim *-s \text { nan }\end{array}$ \\
\hline
\end{tabular}

CHART V. The Proto-Central Cordizleran case marking system 
The reconstruction of the common Nominative markers requires the postulating of several stages of development from PCC.

$\begin{array}{lcc}\text { Stage I } & \text { Proto-Central Cordilleran } & \\ \text { Singular } & & \text { Plural } \\ \text { General } & * \text { di } & \text { General *dadi } \\ \text { Specific } & * \text { di nan } & \text { Specific }\end{array}$

From this stage it is possible to account for the Isinai data by postulating loss of contrast between the general and specific features with concomitant loss of the *nan formative. *di was generalized to mark both singular and plural substantives and *dadi became a plural enclitic on the marked substantive. An enclitic definite article - ad also developed and co-occurs with $d i$ in most environments. 14 The origin of the -ad will be discussed under Locative markers.

The following sentences illustrate the use of the Nominative markers in Isinai.

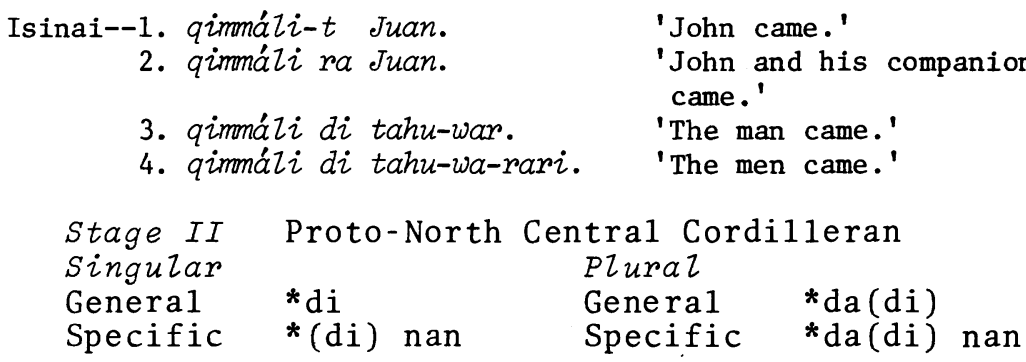

From this stage it is possible to account for Kalinga and for Proto-Nuclear Cordilleran. Kalinga maintains a contrast between indefinite $d i$ and definite din in some Genitive constructions. For example:

Kalinga--5. qanon di bolok nan qawqaw

'Qawqaw (rice water) is pigfood.'

6. qanon din bolokda nan qawqaw. 'Their pig eats qoowqow.'

$d i$ and $d i n$ however no longer function as Nominative markers in Kalinga. 
In discussing the function of case-marking particles in Kalinga, Gieser (1972:22) states, "Substantive phrases in a clause referring to nonpast time are usually marked by particles ending in $n$ ( $s i n$, din and dan), and those in a clause referring to past tense are marked by particles ending in $t$ ( $s i t$, dit and dat)." *di and *(di)nan became respectively $\mathrm{Kla}$. $d i(t)$ and nan for the singular marker. In the plural, *da(di) > Kla. da(t), and *da(di)nan > dan. (Kla. nan and $-n$ are still in alternation in some environments.) The origin of the Kla. - $t$ formative is obscure but may be a reduced form of a particle * $\mathrm{q}+\mathrm{t}$ (> Kla. qot) which currently functions in Kalinga, and other languages (such as Bontok and Isinai) as a conjunction in completed discourse. 15

An alternate explanation is that the $\mathrm{Kla}$. - $t$ formative is a relic of a no longer existing Kalinga demonstrative, either *tu or *ta. It will be seen that Itneg has a - $t$ formative with such a source on its case marking particles. ${ }^{16}$

\begin{tabular}{llll} 
Stage III & Proto-Nuclear Cordilleran \\
Singular & \multicolumn{4}{c}{$\begin{array}{l}\text { Plural } \\
\text { General }\end{array}$} & *di (nan) & General & *da(di) nan \\
Specific & $*(\mathrm{sa})$ nan & Specific & *(da) nan
\end{tabular}

Stage III developed from Stage II by generalizing the use of the formative *nan so that it formed part of each of the common Nominative markers. The formative *di was lost from the specific markers in the Nominative set. A *sa formative was added to the singular specific marker to form a *sa nan/*da nan contrast between singular and plural specific markers. This situation is reflected in Ifugao of Kiangan. Racho (1970) notes that the optional ha formative (<*sa) has no function and is frequently omitted. He indicates that he considers nádan a surface manifestation of underlying danan. The general markers *di nan and *dadi nan were reduced respectively to $d i n$ and dadin, the latter form becoming didan by analogy with the singular form nádan. The ha formative became attached to din in Ifugao by analogy with the hanan marker. Semantically, Ifg. (ha) nan retains a more specific meaning, referring to something which is not present; conversely, (ha)din retains a more general meaning. ${ }^{17}$ 
It appears that Balangaw has completely lost the Nominative set of markers, substituting for them the marker of the Oblique case.

$$
\begin{array}{lll}
\text { Stage IV } & \text { Proto-Kankanay-Bontok } & \\
\text { General } & \text { *nan } & \text { Specific *san }
\end{array}
$$

Stage IV lost the distinctive plural markers. Both Kankanay and Bontok now mark plural substantives by optionally following the marker with a plural demonstrative. (Balangaw likewise marks plural in the same manner.) For example:
Bontok-7. nan laláki
8. nan $d \dot{+} q \dot{+} y d a$ ZaZlaláki
'the man'
'the (those) men'

Bontok may also reduce the demonstrative in this position leaving only the plural formative $d a$, e.g.,

Bontok-9. nan da lallálaki 'the men'

Stage IV also lost *di forms from the common Nominative set, although they still functioned in the Genitive set maintaining the "general" meaning (with $(-n)$ ) as described above for Kalinga (sentences \#5 and 6). The equivalent use in Kankanay is seen in the following examples:

Kankanay--10. qinálan di búsu siya. 'He was enemy-gotten.'18 11. qinálan nan búsu siya. 'The enemy got him.'

In Bontok this function of $d i$ is replaced by $s i$. For example:

Bontok-12. kinnan si qútut nan qúbi. 'The sweet potato was rat-eaten.'

13. kinnan nan qútut nan qúbi. 'A rat ate the sweet potato.'

Kankanay has also retained $d i n$ but it either cooccurs with the personal substantive markers $s i$ and $d a$ to indicate a person who is deceased, or as a common marker indicating a noun with past time relevance, e.g.,

Kankanay--14. Kंg din puslaqit datuna like flashlight these

'Like the former flashlight of these people.' 
The loss of *di from the Nominative set left *nan to carry the general meaning, a function which it has today in both Kankanay and Bontok. The specific meaning is carried by san, a reduction of the earlier *sa nan. In both Kankanay and Bontok san marks a substantive to which special reference is made. It frequently marks a substantive as being within the shared knowledge of speaker and hearer ("the one you and I know about"), and hence is often a substantive whose referent is not present.19

4.3 Oblique markers. The common Oblique markers can be reconstructed for PCC as:

$\begin{array}{ll}\text { General } & * \text { si } \\ \text { Specific } & * \text { si nan }\end{array}$

The general marker is reflected as Isi., Kla., Bon. $s i$, and Ifg. hi. Knk. qis is probably a metathesis of *si. The analogical basis for the metathesis will be discussed in the section on Locative markers. The Bontok form alternates with qas, a metathesized $s a$, which will be discussed further below. Blw. qah which likewise is a metathesis of *ha (<*sa), has replaced the reflex of *si. Some of these languages also have a reduced, consonant enclitic variant which normally occurs following a vowel final stem. In Isinai it is - $t\left(*_{-} s>\right.$ Isi. - $t$, e.g., *q+mis > Isi. qomot), in Bontok and Kankanay it is $-s$, and in Ifugao it is $-h$. The *nan formative was lost in Isinai being replaced by $d i$. Ifugao 20 retained hinan, as have Kankanay and Bontok, the latter two languages also differentiating between nan and san as in the Nominative series. Balangaw and Kalinga have reduced *si nan to $\mathrm{B} 1 \mathrm{w}$. hen and $\mathrm{K} 1 \mathrm{a}$. sin, the Balangaw form becoming a marker for all common substantives in Genitive, Nominative and Oblique cases.

There are problems in the reconstruction of the personal Oblique markers. Bon. qan is the form commonly used in the Guinaang dialect. It is probably an irregular development from *kan which is reflected as such in Bontoc town. Kla. qan probably also derives from *kan, and the Ifugao enclitic - $n$ is also probably from this source. However the Ifugao languages also show reflexes of a form *kay: Kiangan $k e$, Banaue $q e$, Bayninan $q i$, Batad qay.21 Bayninan $q i$ is apparently an irregular development, 
perhaps to differentiate it from an otherwise homophonous postposed conditional marker. Banaue has apparently disambiguated the same two forms by irregularly changing the conditional marker to $q i$. Reflexes of the ${ }^{*}$ kay conditional marker are as follows: Kiangan $k e$, Banaue $q i$, Bayninan $q e$, Batad qay.

Isinai likewise has an $q i$ personal oblique marker. Several possible sources are apparent for this form. Isinai and Ifugao are geographically the closest of the Central Cordilleran languages and have no doubt mutually influenced each other. It is possible that Isi. $q i$ developed from *kay as discussed above for Bayninan, or that Isinai borrowed the Bayninan form. This however is not a strong possibility.

Isi. $q i$ is formally cognate with Inibaloi $q i$, Pangasinan $-y$. But the latter two forms are generally common Nominative markers, not personal Oblique.22 It is not probable that Isinai borrowed the Inibaloi form and switched its functions. Looking at the Northern Cordilleran languages $q i$ also appears. In Ilokano it forms part of the common Oblique marker $q i-t i$. In Gaddang, Oblique markers are $s i$ (common) and $q i$ (personal), corresponding exactly with the forms appearing in Isinai. A1though Isinai is contiguous to the so-called "Christian" Gaddang population in Nueva Vizcaya, it is unlikely that Gaddang borrowed the forms from Isinai since the "Pagan" Gaddang population in Calaccad (South-Eastern Kalinga Province) and Parasiles (Eastern Bontoc Province) also use these forms. The possibility of Isinai borrowing from Gaddang remains, but is considered unlikely. The most satisfactory solution is to consider that both Gaddang and Isinai directly reflect a personal Oblique *qi and a common Oblique *si. These forms would need to be reconstructed for Proto-Cordilleran, since on other grounds it is necessary to assign Isinai and Gaddang to separate subgroups of Cordilleran. We are left then with the necessity of reconstructing for PCC two personal Oblique markers, *kan and *qi, with Proto-Ifugao *kay posing a problem because it is apparently cognate with Tagalog kay, a personal oblique marker found also in other languages of the subgroup to which Tagalog belongs (e.g., Hiligaynon). Returning to *kan and *qi it is not necessary to assume that these were dialectal 
variants of the personal oblique marker. It is more likely that in Proto-Central Cordilleran they occurred in sequence as *kan-i, from Proto-Cordilleran *ka-ni. The equivalent plural form in ProtoCordilleran was *ka-da, but because of the reanalysis of the singular form, in Proto-Central Cordilleran the plural form became *kan-da. Note that the reanalysis of the singular form was probably the result of the reduction of the Genitive *ni to *-n in Proto-Central Cordilleran. The Proto-Cordilleran reconstructions are supported by the Ibanag personal Oblique markers kani (singular) and kada (plura1), as we11 as by the forms of the Ilokano Ob1ique pronouns kani-ak, kada-ta, kada-kayu, kada-kami, etc. Ilokano retains kada for the plural personal marker, but has developed ken(ni) for the singular.

In Isinai, the first part of the re-formation, *kan, changed its function to become the optional marker of a personal Genitive phrase, e.g.,

Isinai--15. qasu-n Juan-ar $\sim$ qasu-n qan Juan-ar 'The dog of John'

16. qinmot qan Juan di qapuxtannar bathed John brother-his-the 'John bathed his brother.'

The second part of *kan-i was retained in Isinai as the personal oblique marker.

Reconsidering Proto-Ifugao *kay in the light of the reconstruction of ${ }^{*} \mathrm{kan}-\mathrm{i}$, it becomes apparent that Lambrecht's suggestion $(1970: 309,325)$ that Kiangan Ifugao ke developed from an earlier kay or $k a+i$ is no doubt correct. Whereas Kankanay, Bontok, and Kalinga reflect only *kan, Proto-Ifugao developed variant forms *kan $>*-n$ and *ka-i $>$ *kay, the former occurring following vowel final stems, the latter following consonant final stems.

4.4 Location and Time markers. A11 of the Central Cordilleran languages mark at least two types of locative: place names and general locations. Several of the languages also distinguish between place names which are distant or unfamiliar and those that are local or familiar. This latter distinction is not rigid however, some place names 
which are local are regularly marked with the "distant" marker. The opposite is not generally true, i.e., distant locations seem never to carry the "local" place name marker.

The markers which appear before time words are generally homophonous with the location markers. The form which marks distant place names also marks past time, the form which marks local place names also marks nonpast time words. General time phrases as "every morning," "when he comes" are marked by the form which also marks general locations.

For Proto-Central Cordilleran it is necessary to reconstruct the following:

Locative markers

Distant place names

Local place names

*qad $\sim *-d$

General location

* qas $\sim *-s$

*qas nan $\sim$ *s nan

Time markers

Past time words

Nonpast time words

General time

$$
\begin{aligned}
& \text { *qad } \sim \text {-d } \\
& \text { *qas } \sim \text {-s } \\
& \text { *qas nan * -s nan }
\end{aligned}
$$

Although it is probable that PCC *qas is a metathesis of an earlier *sa (which is reflected as a locative marker in languages such as Tagalog), there is no evidence that the unmetathesized form was present as a locative or time marker in PCC. The metathesis probably was an analogical change to produce $q a-$ initial markers in the system. Balangaw and Bontok both reflect *qad and *qas. In fact the Balangaw reflex qah has replaced the reflex of the Oblique marker * $\mathrm{si}$ as well as the personal Nominative *si. The dissimilarity of Blw. hi and Blw. qah raises the question of what motivated the substitution of one for the other, especially when the same process appears to be operating in Bontok with $s i$ alternating with qas as the Oblique marker, as well as in the locative and time markers. Both $s i$ and qas have a reduced enclitic form $-s$.

For example:

Bontok--17. qumálaka-s qítab 'Get some beans.' 
Bontok--18. qumálaka-s wákas

19. qumálaka-s dital
'Get some tommorow.'

'Get some at Dital.'

Note also:

20. qumálaka-s nan qítab. 'Get some of the beans.'

21. qumálaka-s nan qajbattaj. 'Get some in the after-

22. qumálaka-s nan qálan. '
granary.'

With homophonony occurring in the enclitic forms, it is not surprising that the surface case distinctions were lost in the full forms as well. The choice of qas or $s i$ in Bontok is now phonologically determined ( $s i$ only occurs after a consonant final stem, qas is used in deliberate speech), although there are some locative phrases where only qas is used, as in the personal locative markers. For example:

Bontok--23. qinálak qas qan da Juan. 'I got (it) from John's place.'

In Kankanay the same process described for Bontok has occurred, except that the reflex of *qas which alternated with $s i$ in the Oblique was treated as a metathesis of $s i$ resulting in qis rather than qas. This form was then generalized, replacing the qas in both the locative and time series. Kankanay went one step further and changed qad to qid by analogy with qis. In Ifugao, $h i$ as a locative marker corresponds to the si alternant described for Bontok, and probably had a parallel development.

The three way contrast of time markers shown in Chart IV for Ifugao indicates distinctions between future time ( $h i$ ), past time (qad) and time distant from the future in either direction, that is, away from 'now' $(d i n) .23$ E.g.,

Bayninan Ifugao--24. qad quwwandi

25. qad qugga

26. (hi) qandani

27. (hi) $m \bar{o} q i$ 'awhile ago'

'yesterday'

'after a while, in a minute'

'tomorrow' 
Bayninan Ifugao-- 28. hi tuluy qalgo

$$
\text { 29. din qalgo }
$$

' in three days; three days from now'

'two days ago'

Isinai shows a reflex of *qad as a past time marker, but suffixed to the time word. It is preceded by the marker si $(\sim-t)$ which occurs as a general marker in both Genitive and Ob1ique cases in Isinai, and has been generalized as a general locative and time marker as we11. For example:

Isinai--30. dumátunqami-t towqon.

'We will arrive next year.'

31. dimmátunqami-t tawqon-ar. 'We arrived last year.'

Past time is treated in CC languages as carrying the feature definite; future time as carrying the feature indefinite. Note the use of san (definite) versus nan (indefinite) in the following Bontok examples:

Bontok--32. qumiyda-s nan qagqagiw. 'They will go in the morning.'

33. qirmityda-s san qagqagiw. 'They went this morning.'

It was probably from the use of -ad as a suffix to mark past time that its function as a definite article developed in Isinai, being suffixed to any substantive which was otherwise marked as definite by Isi. $d i$.

The suffixation of -ad is present also in Bayninan Ifugao but only on a few past time words, for example:

$\begin{array}{rll}\text { Bayninan Ifugao--34. } & \text { hi tawon } & \text { 'next year' } \\ \text { 35. qumäliqami-h tawon } & \text { 'we'll come next } \\ \text { 36. } & \text { qad towön-ad } & \text { 'last year' } \\ \text { 37. qimmaliqami-d towon-ad } & \text { 'we came last } \\ & & \text { year' }\end{array}$

It may be that we see in Bayninan Ifugao the beginning of the development of the process which brought about the enclitic definite article in Isinai. 
5. THE POSITION OF ITNEG IN CC. In Section 2 above and elsewhere in this paper, reference has been made to the fact that Itneg shows evidence of a long period of contact with Ilokano. This contact has resulted not only in extensive lexical borrowing (which has apparently inflated lexicostatistical test scores between Ilokano and Itneg), but also has resulted in the borrowing of various morphological and syntactic features. These include the first person inclusive plural pronoun tayu which is not found elsewhere in CC, nor does it occur in any Northern Cordilleran languages other than Ilokano, a $-g$ final, actor focus verbal prefix (mag-, compare I1k. ag-) where elsewhere in the CC languages $-n$ is the final consonant (Knk. min-, Kla.man-, etc.), as well as some of the case-marking particles, e.g., the singular Genitive marker $n i$, instead of the expected CC $-n$.

The sum of these features has led some investigators to believe that Itneg is in fact genetically most closely related to Ilokano. However a careful examination of the evidence seems to indicate that Itneg is a member of the CC subgroup and is genetically most closely related to Kalinga.

Various anthropologists who have studied the Kalinga and/or the Itneg (otherwise known as Tinguian or Tinggian) have asserted that the Itneg population is the result of a Kalinga expansion into Abra. (For a summary of the evidence see Lambrecht and Billiet, 1970:26-40.) The impressionistic linguistic statements made by Billiet on the basis of 45 years of living with the Kalinga are supported by the following facts.

Itneg reflects PAN * $R$ as $l$ as do all the CC 1 anguages. Ilokano reflects ${ }^{\mathrm{R}}$ as $r$, the other Northern Cordilleran languages reflect ${ }^{*} \mathrm{R}$ as $\mathrm{g}$. Itneg reflects PAN *e as $\dot{t}$, without gemination of the following consonant as in Ilokano (cp. Ilk. bettak 'crack', Itg. $b+t a k$ 'break'; I1k. deppa, Itg. dipa 'arm span'). This gemination is not a process which has developed in Ilokano consequent to a postulated split between Ilokano and Itneg, since it is an innovation which characterizes all of the Northern Cordilleran languages. Kalinga reflects PAN *e as 0 . This 
development occurred after Itneg separated from Proto-Kalinga-Itneg. As indicated in footnote 16 Itneg shares in the PCC innovation of suffixing *-iy to demonstrative roots. Itg. -tuwt developed from PCC *tuw $\dot{t} y$ and $-d i y \dot{t}$ from * diy $\dot{t} y$. The demonstrative formative - ta in Itg. sita 'there, near hearer' is assumed to be borrowed from Ilokano, since it does not occur elsewhere in the CC languages.

An examination of Itneg case-marking particles (see Chart VI) provides additional evidence for considering Itneg to be part of the CC subgroup. The most important piece of evidence is the appearance of the PCC innovation $-n$ as an alternant of $n i$ for the personal singular Genitive marker, e.g., bula ni Juan bula-n Juan 'John's bal1'. That the use of $-n$ is evidence of Itneg's subgrouping with the CC languages rather than areal influence from Kalinga is supported by the fact that a syntactic innovation which was brought about by this reduction (see Section 6 below) is also found in Itneg.

Itneg common noun phrase markers in both Genitive and Nominative cases are the same as the personal markers but with a final formative, either - $t$ or $-d$. This final consonant is probably a reduction of the demonstratives, e.g., bula nit qanak $\sim$ bula nita na qanak 'the ball of this child'; bula nid qanak ? bula nidi na qanak 'the ball of that child'; nit and nid are apparently also acceptable reductions of the other demonstratives nituw $\dot{t}$ and nidiy $\dot{t}$. Thus in the plural also, dat is a reduction of both data and datuwi, and dad of dadi and dadiy $\dot{t}$. The semantic distinction between dadi and dadiy $\dot{t}$ is not clear, but the former is undoubtedly the reflex of PCC * $(-n)$ dadi, and the latter of the demonstrative * diq $\dot{t} y$ discussed in footnote 16 .

The use in Itneg of common markers based on the personal markers $n i$ and $s i$, is probably a result of the borrowing of Ilokano $n i$ in the personal singular Genitive to replace Itg. $-n$, but since in the CC languages $-n$ also marked common noun phrases, the function of the borrowed $n i$ was expanded to include this function also. The inherited $s i$ personal marker expanded its function to include the marking of common noun phrases by analogy with $n i$. 


\begin{tabular}{|c|c|c|c|}
\hline \multirow{3}{*}{ Genitive } & \multicolumn{2}{|r|}{ Personal } & Common \\
\hline & sg. & $\mathrm{ni} \sim-\mathrm{n}$ & $\begin{array}{l}\text { nit } \\
\text { nid }\end{array}$ \\
\hline & pl. & da & $\begin{array}{l}\text { dat } \\
\text { dad }\end{array}$ \\
\hline \multirow{2}{*}{ Nominative } & sg. & si & $\begin{array}{l}\text { sit } \\
\text { sid }\end{array}$ \\
\hline & $\mathrm{pl}$. & da & $\begin{array}{l}\text { dat } \\
\text { dad }\end{array}$ \\
\hline \multirow{2}{*}{ oblique } & sg. & kan $\sim$ kanni & $\begin{array}{l}\text { ta kantuw } \dot{ } \\
\text { kanta, kandi, } \\
\text { kandiy } \dot{ }\end{array}$ \\
\hline & $\mathrm{pl}$. & kada & $\begin{array}{l}\text { kadatuwi, kadata, } \\
\text { kadadi }\end{array}$ \\
\hline Locative & & & di \\
\hline Time & & & kandi, sidi \\
\hline
\end{tabular}

CHART VI. Itneg case-marking particles

In addition to the evidence adduced above, various other pieces of evidence have come to my attention which indicate that if a thorough dialectal study were made of Itneg a much clearer picture of the relationship of Itneg to the CC languages would emerge. Walton 24 has indicated, for example, that -taku is the $1+2 \mathrm{p}$. Nominative pronoun in Banaw Itneg, rather than the borrowed tayu and that Masadit Itneg (spoken in Bucloc and Sallapadan) uses a demonstrative naqoy. Both - taku and naqoy are reflexes of PCC innovations and thus further support the subgrouping of Itneg postulated here. 
6. A SYNTACTIC INNOVATION IN PROTO-CENTRAL CORDILLERAN. Many Philippine languages allow a relatively free ordering of nominal constituents following the verb when these constituents are not pronomina1. However when one of the constituents (either Subject of an active sentence, or the agent or Subject of a passive sentence) is a pronoun, the pronoun necessarily occurs before the other complements.

For example:

Tagalog--38. nakita si Ben ni Pedro
39. nakita ni Pedro si Ben
40. nakita niya si Ben
41. nakita siya ni Pedro

'Pedro saw Ben.'
'Pedro saw Ben.'
'He saw Ben.'
'Pedro saw him.'

But not: *nakita ni Pedro siya

Ilokano--42. inayaban ni Juan ni Maria 'Juan called Mary.'

43. inayaba-k ni Maria 'I called Mary.'

44. inayaban-ak ni Juan 'Juan called me.'

But not: *inayaban ni Juan siak.

The Central Cordilleran languages, however, show a syntactic innovation which required that in passive sentences the Agent obligatorily precede the Subject, regardless of whether or not the Subject was a noun phrase or a pronoun. This was probably a result of the reduction of the Cordilleran Genitive marker *ni to *-n, enclitic to vowel final verb stems.

A11 of the daughter languages reflect this syntactic change although Is inai only retains relics of it. For example:

Bontok--45. qinila-n nan laláki nan qasáwana saw man wife-his

'The man saw his wife.'

46. qiniza-k nan qasáwana 'I saw his wife.'

47. qinila-n nan laláki siya 'The man saw her.'

But not: *qinila siya nan laláki

Note also the following cognate structures:

Kalinga-- 48. binánon din la láqi sáqỏn

Itneg-- 49. binánun nit táqu diyakìn 
Bontok-- 50. binánun nan laláki sakqin

Balangaw--51. binánon hen laláqe haq^n

'The man woke me up.'

In Isinai the following passive paradigm occurs:

$\begin{array}{lll}\text { Isinai--52. } & \text { qinila-naq si tahu-war } & \text { 'The man saw me.' } \\ \text { 53. qinila-taqa-t tahu-war } & \text { 'The man saw you (sg).' } \\ \text { 54. qinila-mita-t tahu-war } & \text { 'The man saw us two.' } \\ \text { 55. siya-t qinila-n di tahu-war 'The man saw him.' } & \text { 'The man saw us } \\ \text { 56. qinila-rami-t tahu-war } & \text { 'The } & \text { (excl).' } \\ \text { 57. qinila-ritaqu-t tahu-war } & \text { 'The man saw us (incl).' } \\ \text { 58. qinila-raqayu-t tahu-war } & \text { 'The man saw you (pl).' } \\ \text { 59. qinila-n di tahu-war dira } & \text { 'The man saw them.' }\end{array}$

That this paradigm has developed from one in which the word order was Verb + Agent + Subject can be assumed from the following facts: (a) third person plural retains the PCC innovated order, with the expected -n clitic Genitive marker. (b) third person singular likewise retains the expected Genitive form, although the Subject pronoun has become preposed to the Verb. (c) The other personal pronouns (except $1 \mathrm{s.}$ ) are the same (or similar to) the free, long form Nominatives in Isinai, leading to the conclusion that the Subject pronoun originally followed the Agent, as in the other CC languages, but later became long form clitic pronouns. In languages such as Ilokano and Tagalog that did not undergo the syntactic innovation discussed in this section, the pronoun in sentences such as these is the same as the short Nominative form which occurs as the Subject of active sentences. (d) The Agent in Isinai, when definite, is regularly preceded by $d i$ and followed by $-a r$, as in the sentences with third person Subjects above. This combination is also the definite marker for Subject nouns. The postulated switch from Verb + Noun Agent + Pronoun Subject to Verb + Pronoun Subject + Noun Agent eliminated the Genitive - $n$ suffix on the verb, leading to possible ambiguity as to the function of the $d i$ marked phrase. To avoid this ambiguity the $d i$ was replaced with $s i(\sim-t)$ which elsewhere in the language marks indefinite nouns (for example out-of-focus objects), but retained the definite suffix -ar on the $s i$ marked noun. 
7. LEXICAL INNOVATIONS WITHIN PCC. The following lexical forms are probably exclusively shared within PCC. Each item has a reflex in Isinai as we11 as at least one of the languages in the North Central Cordilleran subgroup.
1. *qátun
Kla., Itg., Bon., Knk., Ifg., Isi. qátun, Blw. qáton 'hot, to burn oneself.'
2. $* q \dot{q} t+\dot{p}$
Kla. qoton, Itg. qitti, Blw. ma-tan, Bon., Knk., qitin 'mature', Ifg. qoton 'mature pig'
3. *qiba
4. *qigid
5. *qila
6. *bagan
7. *banqtg
8. *dalit
9. *dipag
10. *dugi
11. * * $\dot{g}+\dot{+} \dot{d}$
12. *kilan
13. *kiyat
14. *kupkup
15. *kúgab
16. *liktat
Ifg. $q i b a$, Blw. $q i b \wedge$, Isi. qiva 'sibling'
Kla., Bon., Knk., Blw. qigid, Ifg. qiggid, Isi. qi-qixir 'left (side)' Kla., Bon., Knk., Isi. qila, Blw. qilı 'see' Kla., Bon., Knk., Ifg. bagan, Blw. b^gan, Isi. baxan 'neck' (Possibly a semantic development from *barqan 'molar')
Itg., Knk. banq'g, Kla. banqog, Isi. manqox 'small'
Kla., Bon., Knk., Isi. dalit, Blw. delet, Ifg. dalet 'eel'
Bon., Knk., Blw. dipag, Ifg. dopag, Isi. dopax 'lie on one's back, lie flat', Kla. dopag 'undermatting of thatch.'
Kla., Itg., Blw., Ifg. dugi, Isi. duxi
'husk of rice', Knk. dugi-yan 'rice' (used in tales).
Bon., Blw. g’́gtd, Kla., Ifg., gógod, Isi. goggor 'slice meat'
Itg., Bon. kilan, Knk. kiqan, Kla., Blw., Ifg. qolan, Isi. kolan 'worm'
Bon. kiyat, Kla., Isi. qiyat 'swim'
Bon., Knk. kupkup, Ifg., Isi. qupqup 'skin of human'
Knk. kúgab, Ifg. qúgab 'last night', Isi. $q u x a b$ 'late, afternoon'
Bon., Knk. Ziktat, Isi. Zoqtat 'sudden' 
17. $* 1 \dot{+} t \dot{t} p^{25}$

18. *ibúqu

19. *liglig

20. *1+gab

21. *lúsud

22. *naqid

23. *puntg

24. *putu

25. *sagamsam

26. *sagqtin

27. *sakúku

28. *sipdak

29. *sin-

30. *súkup

31. *tagq $+y$

32. *t+bin

33. $* t+k i n$
Bon., Knk. Zitip, Blw. $\tau_{\wedge t \wedge p}$, Ifg., Isi. Zotop 'dive', Itg. Zitip 'immerse oneself in water'

Kla., Itg., Bon., Knk. Zibúqu, Isi. Zibbu 'cloud'

Kla. liglig 'go around, circumvent', Knk. liglig 'deviate', Ifg. Ziglig 'flanking in battle', Isi. Zixlix 'off the road, to one side'

Knk. I+gab, Isi. Zoxab 'set ablaze', Ifg. Zogab 'conflagration'

Kla., Itg. Zúsud 'upright for a fence', Knk. Zúsud, Itg. Zuhud, Isi. Zusur 'wooden fence'

Kla., Itg., Isi. naqid 'there is none'

Bon., Knk. punig, Ifg. punnog, Isi. punox 'blood sausage'

Bon., Ifg., Isi. putu, Blw. poto 'belly, intestines'

Kla., Bon., Knk. sagamsam, Isi saxamsam

'to remove weeds from growing rice'

Bon., Knk. sagqin, Blw. hagq^n, Ifg. haggon, Isi. saxqon 'near, next to'

Knk. sákuku, Ifg. haqúqu, Isi. saqúqu 'kind of snake'

Bon., Knk. sipdak, Ifg. hopdaq, Isi. sopdaq 'whip, beat in wrestling'

Kla., Bon., Knk., Isi. sin-, Blw. hen-, Ifg. hin- 'one unit'

Kla. súkup 'cap, stopper (e.g., of a bottle)', Bon. súkup 'kind of basket', Knk. súkup 'cover of basket', Ifg. huqup 'lid of vessel', Isi. suqup 'little container for thread'

Bon., Knk. tagqiy, Isi taxqoy 'above, up', Itg. tagqay 'raise', Kla. tanqoy ${ }^{26}$ 'raise, elevate'

Bon., Knk. $t+b \dot{\dagger}$, Ifg., Isi. tobon 'pierce'

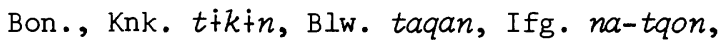
Isi. toqon 'different' 
34. *túbu

35. *wajwan
Kla., Itg., Bon., Knk., Blw., Ifg. túbu, Isi. tuvu 'leaf' (Probably a semantic development from *tubuq 'to grow')

Kla., Itg., Bon., Knk., Blw., Ifg., Isi. wanwan 'river'

The following lexical items are possible exclusive$1 y$ shared innovations within the North Central Cordilleran subgroup. To qualify for inclusion in this group a reconstructed form must have reflexes in Kalinga or Itneg, as well as in at least two other members of the subgroup, that is in Bontok (and/or Kankanay) and Balangaw or I fugao, or in Balangaw and Ifugao.

1. *qákìw

2. *qanuka

3. *qáwil

4. *q+gyat

5. *qikdag

6. *q+i+l

7. *qisitk

8. *qína

9. *qútu

10. *bágiw

11. *dákig

12. *gaman

13. *kan
Bon., Knk. qákiłw, Kla., Blw., Ifg. (Batad) qákow, 27 Ifg. (Amganad) qáko 'steal'

Bon. qanuka, Kla. qanuqa, Ifg., Blw. qanqa, Knk. qarukqa 28 'what's-it'

Kla., Bon., Knk. qawil, Ifg. qáwel 'kind of gift'

Bon., Knk., Blw. q'gyat, Kla. qogyat 'fear'

Bon., Knk. qikdag, Blw. ma-qdig, Kla. qoddag, 29 Itg. qitdag qikdag 'fall'

Itg., Bon qinil, Kla. qonol, Blw. qanal 'nose'

Itg., Bon., Knk. qistk, Ifg. qohoq 'to plant', Kla. qosoq 'to transplant rice' Kła., Itg., Bon., Knk., Ifg. qina, Blw. qios 'ear'

Kla., Itg., Bon., Knk. qútu, Blw. qúto 'cook'

Kla., Bon., Knk., Blw., Ifg. bágiw 'pondfield algae'

Kla., Bon., Knk. dákig, Blw., Ifg. dáqig 'bolt of a door'

Kla., Itg., Bon., Knk., Blw., Ifg. gaman 'head axe'

Kla., Bon., Knk., Barlig, Kadaklan ${ }^{30}$ kan 'say' 
14. *lawa

15. *lukbub

16. *maqid

17. *paláyłn

18. *pánad

19. *sunsun

20. *sápit

21. *táyap

22. *tukdu

23. *tupqal
Kla., Bon., Knk., Blw., Ifg. Zawa 'useless, without purpose, insignificant'

Kla., Bon., Knk., Ifg. Zukbub, 'to lie on one's stomach'

Bon., Knk., Blw. maqid, Ifg. (Batad) miqid, Ifg. (Amganad) maqqid 'there is none' 31

Itg., Bon., Knk. paláyłn, Ifg. paláyun, Blw. paláyin 'a kind of tree'

Kla. pánad 'a level area', Bon. pánad 'foundation of a pondfield', Knk., Ifg. pánad 'level'

Kla., Bon., Knk. sunsun, Blw. honhon, Ifg. huphun 'to smell'32

Itg. (Banaw), Knk. sápit, Blw., Ifg. hápet 'relate; word'

Itg., Blw., Ifg. táyap 'to $\mathrm{fly}$ ', Bon. tayap 'to fly, as a thrown spear', Kla. táyap 'to fly, as something blown by the wind'

Kla., Bon., Knk. tukdu, Blw. tuqdu 'to sit'

Kla., Bon. tunqal, Blw. tonal, Ifg. tunal

'bone', Knk. tunqa 'skull of a small animal'

The following lexical items are exclusively shared by Kalinga and/or Itneg and only one other of the North Central Cordilleran languages and are therefore less persuasive as evidence for this subgroup.

24. *q+b+l

25. *qisna

26. *dapqay

27. $* k+\dot{k g k}+\mathrm{g}$

28. *lagan

29. *lákty

30. *munqul

31. *putaqák
Bon. $q \dot{+} b \dot{+} Z, \mathrm{Knk}, q \dot{+} b \dot{+}, \mathrm{Kla}$. qobol 'wet'33

Kla. qisna, Blw. qisnı 'cooked rice'

Itg., Bon., Knk. dapqay 'rock with a wide flat surface; paved place; men's communal house'

Bon., Knk. kitgkig, Kla. kogkog 'knock, beat, as on a door'

Kla., Itg., Bon., Knk. Zagan 'sand'

Bon., Knk. Zákły, Kla. Záqoy 'termite'

Itg., Kla., Bon. munqul 'summit'

Bon. putaqak, Kla. putáqaq 'white' 
Lexical evidence supporting the subgrouping of BontokKankanay, Balangaw and Ifugao consists of the following (1-11 have reflexes in each of the three branches, 12-19 have reflexes in only two of the branches):

1. *qágid

2. *qáqìiw

3. *qad [qu]wáni

4. *gisgts

5. *kawa

6. *kitin

7. *lakuwan *lumaku

8. *limlim

9. *pádun

10. *púkti

11. *tikid

12. *qaptik

13. *bayag

14. *búyuy

15. *k+nitg

16. *pagpag

17. *qadil

18. *qipit

19. *nilu
Bon., Knk., Blw., Ifg., qágid 'to sharpen to a point, as a stick'

Bon. qáqłił, Blw. qaqqaw, Ifg. (Bayninan) qáo, Ifg. (Amganad) qaqqo 'shadow'

Bon. qadwáni, Knk. qidwáni, Blw. qad qúwın, Ifg. qad quwáni 'today'

Bon., Knk. gisgts, Blw. g^hg^h, Ifg. gosgos 'to slice, as camote leaves'

Bon. kaw-qin (ma-kwa), Blw., Ifg. man-wa

'way; to pass along a trail'

Bon., Knk. kítin, Blw. kéteng, Ifg. qéten

'to pinch'

Bon., Knk. Zakuwan, Zumáku, Blw. Zaqwan,

Ifg. Zumáqu 'to buy'

Bon., Knk. ZimZ im, Ifg. ZomZom 'rain storm, typhoon', Blw. ZimZ im 'mist'

Bon., Ifg. pádun, Blw. pádon 'similar'

Bon. púkil, knk. púkł, Blw. póqal, Ifg. púqol 'shoulder'

Bon., Knk. tikid, Blw. téqed, Ifg. tíqid 'ascend'

Bon., Knk. qaptik, Blw. qatteq 'short'

Bon., Knk. bayag, Blw. b^y^g 'old, of an object'

Bon., Knk., Blw. búyuy 'a boil'

Bon. kintg, Blw. k^n^g 'firm, hard'

Bon., Knk., Blw. pagpag 'forest'

Blw. qadal, Ifg. qadol 'body'

Blw. na-qpat, Ifg. na-qpot (qopot) 'wet'

Blw., Ifg. nilu 'dull' 
${ }^{1}$ Data upon which this paper is based were gathered first under the auspices of the Summer Institute of Linguistics, Philippines. Subsequently my research has been funded by University of Hawaii Intramural Research Grants for which I hereby express my gratitude. Thanks are also due to the following members of the Summer Institute of Linguistics who allowed me access to their data and who discussed various problems with me related to this paper: Richard Gieser (Kalinga), Charles Walton (Itneg), and Joanne Shetler (Balangaw). Research on Isinai was conducted during the summer of 1973. I wish to thank Mr. Isabelo Gonzales of Bambang, Nueva Vizcaya for his patient help.

${ }^{2}$ An earlier decision to refer to this group of languages by the simpler term Igorot, has been abandoned in favor of the term Central Cordilleran. The term Igorot (see Scott 1962) is still considered to have pejorative connotations in various parts of the Philippines, and although most of the groups included in this subgroup call themselves Igorots, neither the Ifugao nor the Isinai do. Moreover several groups that have been referred to in the anthropological literature as Igorots, such as the Inibaloi, are not included in this subgroup.

${ }^{3}$ The following language abbreviations will be used,

\begin{tabular}{|c|c|c|c|}
\hline Blw. & Balangaw & Kla. & Kalinga \\
\hline Bon. & Bontok & $\mathrm{Kln}$. & Kallahan \\
\hline Ifg. & Ifugao & Knk. & Kankanay \\
\hline Ilk. & Ilokano & CC & Central Cordilleran \\
\hline Ilt. & Ilongot & NC & Nuclear Cordilleran \\
\hline Isi. & Isinai & NCC & North Central Cordilleran \\
\hline Itg. & Itneg & PAN & Proto-Austronesian \\
\hline Ivt. & Ivatan & PCC & Proto-Central Cordilleran \\
\hline & & $\mathrm{PPH}$ & Proto-Philippines \\
\hline
\end{tabular}

${ }^{4}$ Such as PAN *R $>\tau$, and use of an $-n$ final actor focus prefix (e.g., Ini. man-, Knk. min-) rather than the equivalent $-g$ final form (e.g., Ilk. ag-), etc.

${ }^{5}$ Unfortunately, Thomas and Healey do not provide in their tables the evidence upon which this subgrouping is based. Their subgrouping of Kalinga and Tingguian with the IlokanoCagayan branch appears only on their tree (1962:23). In their discussion they define the Ilokano-Cagayan branch as consisting of Agta, Gaddang, Atta, Ibanag, Isneg and Ilokano, and note that 
"the internal unity of the group is rather loose knit, with intrabranch comparisons ranging from $44 \%$ to about $60 \%$ (1962:25). The status of Kalinga and Tingguian are not discussed.

${ }^{6}$ PAN forms are taken from Zorc (1971), who cites the source for each item. The PCC forms are in most cases reconstructed on the basis of the evidence appearing in Bontok.

${ }^{7}$ There are a few problem cases where * $R$ is apparently reflected as $g$ in the CC languages. In all cases the forms also show $g$ reflexes in Ilokano, where $r$ is the usual reflex. The problem is discussed in Conant (1911) with reference to Ilokano, and by Reid (1972) with reference to the NCC languages. $l$ is also the reflex of * $R$ in Itneg, a language which shows surface similarity to Ilokano, but which, I believe, subgroups with CC.

${ }^{8}$ Llamzon (1969:22) cites *sanDar 'lean' > Ifg. handag as evidence for PAN $*-r>$ Ifg. $-g$. However, the reconstruction is inaccurately cited. Dempwolff reconstructs the form with a final $* R$, so that the Ifugao form is another example of Conant's "stereotype" $g$ reflex of $* R$, rather than an irregular reflex of *r.

${ }^{9}$ The irregular first vowel is a result of assimilation to the following vowel. Note also the doublet *búgaw 'to shout' with an irregular $* R_{3}>*$ g reflex.

10 PCC *siltw is ręflected in Bontok as siltiw 'pitch pine torch'. A doublet silaw also occurs meaning 'kerosene lantern or other nonindigenous light'.

${ }^{11}$ Comparison with the Bontok form maklun 'dry up' (from ma+ kulun) shows that Balangaw has metathesized the first two root consonants. Blw. maqlon reflects an earlier *ma- $+*$ qolon.

$12 * \mathrm{~b}>m$ is unexplained. It is possibly an analogical development with the man- verbal prefix.

13 The forms of the Kalinga pronouns differ slightly from those appearing in Reid 1971:21. Most of the Kalinga forms in this paper were provided by C. R. Gieser and represent those dialects of Kalinga in which the $*_{k}>q$ rule did not operate.

${ }^{14}$ See Paz 1965 for a full discussion of the function of Isi. -ad. Several variants of -ad occur, such as -ar, -war and $-w a$.

${ }^{15}$ See Gieser 1972:29. 
${ }^{16}$ Since demonstratives are not discussed elsewhere in this paper, the forms will be included here. Only the basic demonstratives are given here, they may occur with various case marking particles depending on the functions they perform within the sentence.

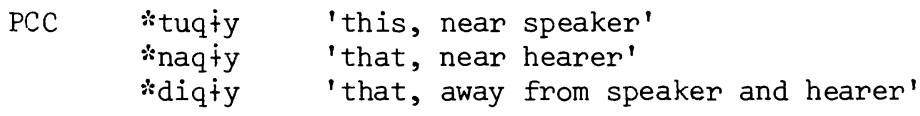

The following charts give the Nominative demonstratives in the daughter languages.

\begin{tabular}{|l|l|l|l|}
\hline \multicolumn{1}{c}{ Isi. } & \multicolumn{1}{c}{ Kla. } & Itg. & Bon.-Knk. \\
\hline tasie satie & siyána & situwi & naçay \\
\hline satu & siyánat & sita & sana \\
\hline sadio & siyádi & sidiyt & diłqty \\
\hline
\end{tabular}

\begin{tabular}{|c|c|c|}
\hline Blw. & Ifg. (Amganad) & Ifg. (Batad) \\
\hline yato & túwe & hitugwoy \\
\hline yaha & náye & hinugwoy \\
\hline yadi & díye & hidugwoy \\
\hline
\end{tabular}

The addition of the final *-qiy to the demonstrative roots is considered to be an innovation in PCC. Although lost from several of the forms it is retained in some form in most of the daughter languages, e.g., Isi. sadio (with loss of final *-y), Itg. situwt and sidiyt (also with loss of final *-y), Bon.-knk. naqay and $d \dot{+} q \dot{+} y$ (with vowel harmony). Amganad Ifugao regularly reflects *-ty as $-e$, e.g., bale < *balty 'house'. Butad Ifugao reflects the same sequence as -oy, e.g., baloy 'house'.

The fact that Ilokano shows forms which seem to reflect this innovation (especially Ilk. diay, but also the $-y$ final forms toy and tay) is problematic, since Ilokano does not on other grounds seem to group with the CC languages, and the *-qiy final forms do not appear elsewhere in the Cordilleran languages. 
Rather than reconstruct *-qiy for Proto-Cordilleran on the basis of two witnesses (i.e., Ilokano and PCC), it would seem preferable to consider that at least diay and toy are the result of early borrowing from PCC or one of its daughter languages.

A fuller study than is possible here is necessary to account for the various phonological and semantic shifts that have taken place in the demonstratives of the various CC languages.

${ }^{17}$ The origin of *sa is unclear. It may have been present in PCC in the form *say (from an earlier *sa $+* i$ ) as the marker of a pre-predicate topicalized phrase, a function that it retains (as hay) in some areas of Ifugao, as well as in Inibaloi and Pangasinan, Southern Cordilleran languages. In Isinai sa is retained as a formative on sentence initial demonstratives, e.g., satu, satie and sadio.

${ }^{18}$ Donna Hettick (personal communication) states that in Kankanay this function of $d i$ generally occurs in embedded sentences. She provides the following additional examples from text (retaining her orthography): 1. Ta wad-ay (kanen di an-akda). 'So that there will be (food for their children).' 2. Kedeng di is am-coma ay kaseseg-ang is (binadangan di anito). 'That is the only old man who was pitiful whom (the spirits helped).' 3. Dapay maid somasaa ta ket no (pinatey di bango). 'But he didn't return home because he was (killed by a wild pig).' The embedded sentences and their translations have here been placed in parentheses. In each instance these sentences come from underlying non-actor focus or "passive" constructions, the $d i$ phrase specifying a general agent.

${ }^{19} \mathrm{Scott}(1966: 250)$ discusses an archaic use of $\mathrm{Knk}$. di as follows: "In the language of Sagada prayer texts $d i$ is used in a way in which it is used only rarely in colloquial speech--to introduce the object of an objective verb." This would be in my terminology the subject of a non-actor focus sentence. One other Nominative function which $d i$ has retained in Kankanay (and the equivalent $s i$ in Bontok) is the indefinite subject of some nonverbal sentences, e.g., Naqay di madindin 'Here are vegetables' (as in announcing vegetables for sale), versus Naqay nan madindin 'Here are the vegetables.'

${ }^{20}$ Racho (1970) does not mention whether the oblique marker $h i$ may cooccur with nan or any other form, but Newell (1964) lists hinan as a Batad Ifugao Oblique form.

${ }^{21}$ This and the following Ifugao data are from Harold $c$. Conklin (personal communication). The analysis is my own. 
${ }^{22}$ In Pangasinan $-y$ may also mark common Oblique phrases.

${ }^{23}$ These comments and the associated Ifugao data are from Harold C. Conklin (personal communication).

${ }^{24}$ Personal communication.

${ }^{25}$ Zorc notes (personal communication) that *litip is related by metathesis and shimmer (alternation of only one distinctive feature) to $\mathrm{PPh}$ *dələp 'to dive', compare Tagalog lirip, Aklanon yuróp, Bikol ladóp 'to dive (into water)'.

${ }^{26}$ With unexplained $* g>0$.

${ }^{27}$ The presence of $k$ in this form as well as in the following Amganad Ifugao form where in each of these languages $q$ is expected, is unexplained.

${ }^{28}$ The epenthetic $q$ in this form is probably the result of a back formation from the suffixed verbal form qanukqin < *qanukaqin.

${ }^{29} \mathrm{The} \mathrm{Kla}$. and Itg. forms show assimilation of the velar stop to the following alveolar stop.

${ }^{30}$ Barlig and Kadaklan are languages spoken in the barrios of the same name, located geographically between Bontoc and Balangaw. They may be referred to likewise as Eastern Bontoc.

${ }^{31}$ This form is probably a development of an earlier "naqid with reflexes in Kla., Itg., and Isi. However it may be that the two forms were alternants in PCC.

${ }^{32} \mathrm{An}$ apparent cognate also appears in Kallahan (Kayapa). It is possibly a borrowing from Ifugao.

${ }^{33}$ The form qebel 'wet' also occurs in Kallahan (Kalanguya) and may be the result of an early borrowing.

\section{REFERENCES}

Conant, Carlos E. 1911. The RGH law in Philippine languages. Journal of the American Oriental Society $31: 70-85$. 
Dyen, Isidore. 1965. A lexicostatistical classification of the Austronesian languages. Supplement to International Journal of American Linguistics, Vol. 31. Memoir 19.

Gieser, C. R. [ichard]. 1970. The morphophonemic system of Guininaang (Kalinga). Philippine Journal of Linguistics 1(2):52-68.

- 1972. Kalinga sequential discourse. Philippine Journal of Linguistics $3(1): 15-34$.

Lambrecht, Francis, and Francisco Billiet. 1970 . Studies on the Kalinga ulZalim and Ifugao orthography. Baguio, Catholic School Press.

Llamzon, Teodoro A. 1969. A subgrouping of nine Philippine languages. The Hague, Martinus Nijhoff.

Mendiole, Francisco. n.d. Diccionario IsinayEspano1. (Unpublished ms.) Manila, Santo Tomas University Archives.

Newe11, Leonard E. 1956. Phonology of the Guhang Ifugao dialect. Philippine Journal of Science $85(4): 523-539$.

1964. Independent clause types of Batad Ifugao. Oceanic Linguistics 3(1):171-199.

Paz, Consuelo J. 1965. - ad in Isinai. Asian Studies $3(1): 114-125$.

Racho, Alberto L. 1970. Some phrase-structure rules for Kiangan Ifugao noun and verb phrases. Philippine Journal of Linguistics 1(2):85-97.

Reid, Lawrence A. 1963. Phonology of Centra1 Bontoc. Journal of the Polynesian Society $72(1)$ : 21- 26 .

- 1964. A matrix analysis of Bontoc casemarking particles. Oceanic Linguistics 3(1):116137 .

- (Ed.). 1971. Philippine minor 1anguages: word 1 ists and phonologies. Oceanic Linguistics Special Publication No. 8. Honolulu, University Press of Hawaii. 
- 1972. Kankanay and the problem * $R$ and ${ }^{*} 1$ reflexes. University of Hawaii Dept. of Linguistics Working Papers in Linguistics 4(8): $47-64$.

\section{(Unpublished)}

1973. Isinai field notes.

(forthcoming) Bontoc-English dictionary. Pacific Linguistics, Series C.

Scheerer, 0tto. 1918. The particles of relation of the Is inai language. 's-Gravenhage, Martinus Nijhoff.

\section{- 1921. Kalinga texts from the}

Ba1ba1asang-Ginaang group. Philippine Journal of Science 19:175-207.

Scott, William Henry. 1962. The word IGOROT. Philippine Studies 10(2):234-248.

$$
\text { - 1966. Articles in Sagada Igorot. In: }
$$

On The Cordillera, pp. 237-252. Manila, MCS Enterprises.

Shetler, Joanne. 1964. Morphophonemic change in Balangao. (Unpublished ms.) Manila, Summer Institute of Linguistics.

1966. Balangao phonemes. Linguistic Circle of Canberra Publications, Series-A 8:1-7. 1968. Balangao non-verbal nuclei. Asian Studies 6(2):208-222.

Thomas, David, and Alan Healey. 1962. Some Philippine language subgroupings: a lexicostatistical study. Anthropological Linguistics 4:29-33.

Zorc, R. David. 1971. Proto-Philippine finder list. (Unpublished ms.) Ithaca, N.Y., Corne11. 
http://www.jstor.org

\section{LINKED CITATIONS \\ - Page 1 of 1 -}

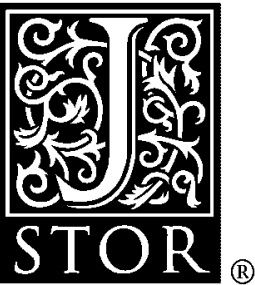

You have printed the following article:

\section{The Central Cordilleran Subgroup of Philippine Languages}

Lawrence A. Reid

Oceanic Linguistics, Vol. 13, No. 1/2, Papers of the First International Conference on Comparative Austronesian Linguistics, 1974: Proto-Austronesian and Western Austronesian.

(Summer - Winter, 1974), pp. 511-560.

Stable URL:

http://links.jstor.org/sici?sici=0029-8115\%28197422\%2F24\%2913\%3A1\%2F2\%3C511\%3ATCCSOP\%3E2.0.CO\%3B2-Q

This article references the following linked citations. If you are trying to access articles from an off-campus location, you may be required to first logon via your library web site to access JSTOR. Please visit your library's website or contact a librarian to learn about options for remote access to JSTOR.

\section{References}

\section{The RGH Law in Philippine Languages}

Carlos Everett Conant

Journal of the American Oriental Society, Vol. 31, No. 1. (1911), pp. 70-85.

Stable URL:

http://links.jstor.org/sici?sici=0003-0279\%281911\%2931\%3A1\%3C70\%3ATRLIPL\%3E2.0.CO\%3B2-Z

\section{Independent Clause Types of Batad Ifugao}

Leonard E. Newell

Oceanic Linguistics, Vol. 3, No. 1, Papers in Philippine Linguistics. (Summer, 1964), pp. 171-199.

Stable URL:

http://links.jstor.org/sici?sici=0029-8115\%28196422\%293\%3A1\%3C171\%3AICTOBI\%3E2.0.CO\%3B2-X

\section{A Matrix Analysis of Bontoc Case-Marking Particles}

Lawrence A. Reid

Oceanic Linguistics, Vol. 3, No. 1, Papers in Philippine Linguistics. (Summer, 1964), pp. 116-137.

Stable URL:

http://links.jstor.org/sici?sici=0029-8115\%28196422\%293\%3A1\%3C116\%3AAMAOBC\%3E2.0.CO\%3B2-O 